FEDERAL RESERVE BANK OF SAN FRANCISCO

WORKING PAPER SERIES

\title{
Measuring the Natural Rate of Interest: International Trends and Determinants
}

\author{
Kathryn Holston and Thomas Laubach \\ Board of Governors of the Federal Reserve System \\ John C. Williams \\ Federal Reserve Bank of San Francisco
}

December 2016

Working Paper 2016-11

http://www.frbsf.org/economic-research/publications/working-papers/wp2016-11.pdf

\section{Suggested citation:}

Holston, Kathryn, Thomas Laubach, John C. Williams. 2016. "Measuring the Natural Rate of Interest: International Trends and Determinants.” Federal Reserve Bank of San Francisco Working Paper 2016-11. http://www.frbsf.org/economic-research/publications/workingpapers/wp2016-11.pdf

The views in this paper are solely the responsibility of the authors and should not be interpreted as reflecting the views of the Federal Reserve Bank of San Francisco or the Board of Governors of the Federal Reserve System. 


\title{
Measuring the Natural Rate of Interest: International Trends and Determinants*
}

\author{
Kathryn Holston Thomas Laubach \\ John C. Williams
}

December 15, 2016

\begin{abstract}
U.S. estimates of the natural rate of interest - the real short-term interest rate that would prevail absent transitory disturbances - have declined dramatically since the start of the global financial crisis. For example, estimates using the Laubach-Williams (2003) model indicate the natural rate in the United States fell to close to zero during the crisis and has remained there into 2016. Explanations for this decline include shifts in demographics, a slowdown in trend productivity growth, and global factors affecting real interest rates. This paper applies the Laubach-Williams methodology to the United States and three other advanced economies - Canada, the Euro Area, and the United Kingdom. We find that large declines in trend GDP growth and natural rates of interest have occurred over the past 25 years in all four economies. These country-by-country estimates are found to display a substantial amount of comovement over time, suggesting an important role for global factors in shaping trend growth and natural rates of interest.

JEL classification: C32, E43, E52, O40.
\end{abstract}

Keywords: natural rate of output, monetary policy rules, Kalman filter, trend growth.

${ }^{*}$ This paper has benefitted from comments by our discussants Emanuel Mönch and Kenneth West and other participants at the 2016 NBER ISOM conference as well as from discussions with Vasco Cúrdia, Marc Giannoni, Benjamin Johannsen, Oscar Jorda, Elmar Mertens, and Edward Nelson. We also thank representatives from the European Central Bank for making available the Area-Wide Model database and the Bank of England for sharing results from their DSGE model. The views expressed herein are those of the authors and do not necessarily reflect those of the Board of Governors, or anyone else in the Federal Reserve System.

Holston: Board of Governors of the Federal Reserve System, Kathryn.A.Holston@frb.gov.

Laubach: Board of Governors of the Federal Reserve System, Thomas.Laubach@frb.gov.

Williams: Federal Reserve Bank of San Francisco, John.C.Williams@sf.frb.org. 


\section{Introduction}

Since Knut Wicksell introduced in 1898 the idea of the natural rate of interest- which we define to be the real short-term interest rate consistent with output equaling its natural rate and constant inflation - it has played a central role in macroeconomic and monetary theory (Wicksell, 1936). The natural or "equilibrium" real interest rate provides a benchmark for measuring the stance of monetary policy, with policy expansionary (contractionary) if the short-term real interest rate lies below (above) the natural rate. This role is illustrated clearly in monetary policy rules such as the Taylor (1993) rule, according to which the real interest rate exceeds the natural rate when inflation exceeds its target rate and vice versa, all else equal. It also provides an anchor for the behavior of interest rates more generally, once cyclical or other factors have died out.

Although economic theory provides insights into the various factors affecting the natural rate of interest (see, for example, Congressional Budget Office 2014; International Monetary Fund 2014; Council of Economic Advisers 2015; Eggertsson et al. 2015; Rachel and Smith 2015; Pescatori and Turunen 2015; Hall 2016; Gagnon et al. 2016), measurement of the natural rate of interest has proven more challenging. This arises because the natural rate, like other latent variables, must be inferred from the data rather than directly observed. This is a particularly relevant topic today. Sustained extraordinarily low interest rates in most advanced economies since the global financial crisis have heightened interest in the question of whether the natural rate of interest has permanently declined and why.

Analysis based on U.S. data suggests that the natural rate of interest has moved significantly lower over the past quarter century, with a sharp drop occurring over the past decade (Williams 2015). This finding is robust to alternative methodologies (Hamilton et al. 2015; Kiley 2015; Lubik and Matthes 2015; Laubach and Williams 2016; Johannsen and Mertens 2016; Juselius et al. 2016). In this paper, we extend this analysis to other advanced economies. ${ }^{1}$ We estimate a version of the Laubach and Williams (2003) model of the natural rate of interest, originally developed for the U.S. economy, using data from four economies: the United States, Canada, the Euro Area, and the United Kingdom. This model applies the Kalman filter to data on real GDP, inflation, and the short-term interest rate to extract highly persistent components of the natural rate of output, its trend growth

\footnotetext{
${ }^{1}$ For earlier studies on the natural rate of interest in the Euro Area, see Giammariou and Valla (2003), and Mésonnier and Renne (2007).
} 
rate, and the natural rate of interest.

Our approach contrasts with other research that has focused on short-term fluctuations in the natural rate of interest, assuming the longer-run value is constant (Neiss and Nelson 2003, Woodford 2003, Andres et al., 2009, Barsky et al., 2014). Recent analysis using dynamic stochastic general equilibrium (DSGE) models also finds evidence of a large decline in the natural rate of interest since the onset of the global financial crisis (Cúrdia 2015; Cúrdia et al., 2015; Goldby et al., 2015). Although the definitions and methods differ across studies, we view the shorter-term perspective in these studies to be complementary to our longer-run approach.

Our analysis yields four key results. First, we find evidence of time-variation in the natural rate of interest in all four economies. Second, there is a downward trend in estimated natural rates of interest: Toward the end of our sample, the estimated natural rates of interest in all four economies have fallen to historically low levels. This is in large part explained in our model by a significant decline in the estimated trend growth rates found in all four economies, but other highly-persistent factors also appear to be at work. We find no evidence that the natural rates are moving back up recently. Third, although estimation is done on a economy-by-economy basis, there is substantial comovement in the estimates of the natural rates of interest and trend GDP growth across economies. This suggests an important role for so-called global factors influencing the natural rates. Finally, the estimates of the natural rate of interest are highly imprecise, reinforcing a key finding of the original Laubach and Williams (2003) paper. In fact, the natural rate estimates for the other three economies are more imprecise than those for the United States.

Our finding of sizable declines in the natural rate of interest in several advanced economies is consistent with the results of other studies that use various approaches to estimate the natural rate. For example, Constâncio (2016) reports sharp declines in estimates of the natural rate in the Euro Area from three different models. Similarly, Mendes (2014) finds evidence of a significant decline in the natural rate in Canada. Fujiwara et al. (2016) estimate that the natural rate of interest has declined to close to zero in Japan. The coincident decline in the estimated natural rate across all of these countries highlights the importance of global factors in determining the natural rate.

The paper is organized as follows. The second section lays out the theoretical model and its empirical counterpart. The third section reports the estimation results. The fourth sec- 
tion analyzes the movements in the natural rates of interest over time and the comovement across economies. The final section concludes.

\section{An Empirical Framework for Estimating the Natural Rate}

Our empirical approach to estimating the natural rate of interest draws on two separate strands of literature. As discussed in the introduction, we follow Wicksell in defining the natural rate as the real rate of interest consistent with stable inflation and output being at its natural rate. This definition is akin to the one developed in the DSGE literature (e.g. Woodford 2003), and hence we build on the New Keynesian framework of a Phillips curve relationship and an intertemporal IS equation to describe the dynamics governing the output gap and inflation as a function of the real rate gap. However, we relax the assumptions about the steady state that most DSGE models use to derive log-linear approximations of the dynamics of inflation and the output gap. In particular, key parameters that are being treated as fixed in that literature, such as the growth rate of technology and the rate of time preference of the representative household, may in fact be subject to highly persistent, but difficult-to-detect fluctuations (e.g. Stock and Watson 1998). Thus, whereas in the DSGE literature the natural rate of interest is a stationary linear combination of transitory shocks to preferences and technology, in our framework we explicitly allow for the natural rate to be affected by low-frequency nonstationary processes. ${ }^{2}$

\subsection{Description of the model}

A useful starting point for modeling the natural rate of interest is the neoclassical growth model. For a representative household with CES preferences, that model implies that the natural rate of interest varies over time in response to shifts in preferences and the growth rate of output. In a non-stochastic steady state, household intertemporal utility maximization yields the relationship between the steady-state real one-period interest rate $r^{*}$ and steady-state growth:

$$
r^{*}=\frac{1}{\sigma} g_{c}+\theta
$$

\footnotetext{
${ }^{2}$ As discussed below, a further difference between our measure of the natural rate and that from DSGE models is that we allow for shocks that have transitory effects on the output gap and inflation but that we do not measure as part of the natural rate, so as to focus on the low-frequency determinants of that rate. By contrast, the natural rate concept estimated in DSGE models is defined as the rate that achieves price stability period-by-period.
} 
where $\sigma$ denotes the intertemporal elasticity of substitution in consumption, $g_{c}$ is the growth rate of per capita consumption, and $\theta$ is the rate of time preference. This steady-state relationship is shared by standard monetary DSGE models, and hence the value given by (1) provides the appropriate intercept for simple interest rate rules in such models.

The purpose of our study is to model the natural rate of interest as a time-varying process that is subject to potentially permanent changes and to provide estimates of this process for several major economies. Roberts (2001), Edge et al. (2007), and Kahn and Rich (2007) provide evidence of shifts in the trend growth rate of labor productivity in the United States, suggesting one source of persistent movements in the natural rate of interest; other potential sources of highly persistent changes in $r^{*}$ could be related to shifts in fiscal policy (Laubach 2009) or changes in the global supply of savings (Bernanke 2005, Council of Economic Advisers 2015).

Given our focus on the international dimension of influences and determinants of the natural rate, we start from the inflation and output gap dynamics described by the openeconomy version of the New Keynesian model (Galí 2008). These dynamics are summarized by a Phillips curve

$$
\pi_{H, t}=\beta E_{t}\left[\pi_{H, t+1}\right]+\kappa \tilde{y}_{t}
$$

and an IS equation of the form

$$
\tilde{y}_{t}=E_{t}\left[\tilde{y}_{t+1}\right]-\sigma^{-1}\left(i_{t}-E_{t}\left[\pi_{H, t+1}\right]-r_{t}^{n}\right)
$$

In these equations, $\pi_{H, t}$ denotes the growth rate of prices of domestically produced goods, $\tilde{y}_{t}$ the output gap, and $i_{t}$ the safe one-period nominal interest rate. The parameters $\kappa$ and $\sigma$ in these equations are functions of underlying parameters describing households' preferences and technology, such as the intertemporal elasticity of substitution in consumption, the substitutability of home and foreign goods in households' preferences, the price adjustment frictions etc.

It is worth noting two properties of the variable $r_{t}^{n}$ in (3). In the simple model (2)-(3), this variable summarizes all shocks affecting inflation and the output gap, and setting the real rate gap $i_{t}-E_{t}\left[\pi_{H, t+1}\right]-r_{t}^{n}$ to zero period-by-period completely stabilizes these two variables. Second, in contrast to a closed economy, the variable $r_{t}^{n}$ depends not only on expected domestic output growth but in general also on expected world output growth. 
While we will depart in the following from the first property, the dependence of the natural rate of interest on global as well as domestic conditions is central to our analysis.

The equations we use for estimating the natural rate of interest relax the restrictions imposed by the New Keynesian model along two dimensions. First, we work with reducedform equations that are somewhat agnostic about the precise lead-lag relationships among the endogenous variables. Doing so reduces the risk that our natural rate estimates are unduly affected by estimates of structural parameters based on potentially misspecified output gap and inflation dynamics. Second, we allow for the presence of shocks that affect the output gap and inflation but not the natural rate of interest, which we define as a low-frequency concept. In particular, we estimate the following equations:

$$
\begin{aligned}
& \tilde{y}_{t}=a_{y, 1} \tilde{y}_{t-1}+a_{y, 2} \tilde{y}_{t-2}+\frac{a_{r}}{2} \sum_{j=1}^{2}\left(r_{t-j}-r_{t-j}^{*}\right)+\epsilon_{\tilde{y}, t} \\
& \pi_{t}=b_{\pi} \pi_{t-1}+\left(1-b_{\pi}\right) \pi_{t-2,4}+b_{y} \tilde{y}_{t-1}+\epsilon_{\pi, t} .
\end{aligned}
$$

where $\tilde{y}_{t}=100 *\left(y_{t}-y_{t}^{*}\right), y_{t}$ and $y_{t}^{*}$ are the logarithms of real GDP and the unobserved natural rate of output, respectively, $r_{t}$ is the real short-term interest rate, $\pi_{t}$ denotes consumer price inflation, and $\pi_{t-2,4}$ is the average of its second to fourth lags. ${ }^{3}$ The presence of the stochastic terms $\epsilon_{\tilde{y}, t}$ and $\epsilon_{\pi, t}$ captures transitory shocks to the output gap and inflation, while movements in $r_{t}^{*}$ reflect persistent shifts in the relationship between the real shortterm interest rate and the output gap (Williams 2003). The distinction between shocks of different persistence reflects our focus on a concept of the natural rate of interest as reflected in the intercept of simple interest rate rules; more transient shocks would leave this intercept unchanged, as the monetary policy response to such shocks would be governed by the response to output and inflation gaps prescribed by such a rule.

Based on the theoretical link between the natural rate of interest and output (or consumption) growth noted above, we assume that the law of motion for the natural rate of interest is given by:

$$
r_{t}^{*}=g_{t}+z_{t}
$$

where $g_{t}$ is the trend growth rate of the natural rate of output and $z_{t}$ captures other

\footnotetext{
${ }^{3}$ The open-economy version of the New Keynesian Phillips curve (2) describes a relationship for homegoods inflation $\pi_{H, t}$. In the absence of data for such a concept, we use measures of consumer price inflation described in the Appendix.
} 
determinants of $r^{*}$. Note that we assume a one-for-one relationship between the trend growth rate of output and the natural rate of interest, which corresponds to assuming $\sigma=1$ in equation 1. In Laubach and Williams (2003), we estimated this relationship and found a coefficient of close to unity. Because this relationship is not well identified in the data, we chose to impose a coefficient of unity. ${ }^{4}$

We specify log potential output as a random walk with a stochastic drift $g$ that itself follows a random walk:

$$
\begin{aligned}
y_{t}^{*} & =y_{t-1}^{*}+g_{t-1}+\epsilon_{y^{*}, t}, \\
g_{t} & =g_{t-1}+\epsilon_{g, t} .
\end{aligned}
$$

This specification implies that potential output is integrated of order 2. In particular, an innovation $\epsilon_{y^{*}, t}$ has a permanent effect on the level of potential output, but only a one-period effect on its rate of change, while an innovation $\epsilon_{g, t}$ permanently affects the growth rate of potential output. Stock and Watson (1998) examine the hypothesis that U.S. log real GDP over the post-WW II period is integrated of order 2 and find evidence in support of a slowmoving and apparently nonstationary trend growth rate. We view the $\mathrm{I}(2)$ specification as agnostic for the purpose of estimation, as it avoids having to estimate the unconditional mean of real GDP growth. Finally, we assume that $z$ also follows a random walk,

$$
z_{t}=z_{t-1}+\epsilon_{z, t}
$$

We assume $\epsilon_{y^{*}, t}, \epsilon_{g, t}$, and $\epsilon_{z, t}$ are normally distributed with standard deviations $\sigma_{y^{*}}, \sigma_{g}$, and $\sigma_{z}$ respectively and are serially and contemporaneously uncorrelated. Equations (7)-(9) constitute the transition equations of our state-space model.

\subsection{Empirical implementation}

Given that the model is linear in the unobserved state variables, we apply the Kalman filter to estimate, for each economy, the natural rate of output, its trend growth rate, and the natural rate of interest (or alternatively the component $z$ unrelated to trend growth). The data and specifics of model variables are described in the Appendix.

The time series and survey evidence suggests that real GDP growth, labor productivity

\footnotetext{
${ }^{4}$ See Hamilton et al. (2015) and Laubach and Williams (2016) for further discussion.
} 
growth, and real interest rates are subject to highly persistent changes masked by volatile transitory shocks. Maximum likelihood estimates of the standard deviations of the innovations to $z$ and the trend growth rate, $\sigma_{g}$ and $\sigma_{z}$, are therefore likely to be biased towards zero owing to the so-called "pile-up problem" discussed in Stock (1994). We therefore use Stock and Watson's (1998) median unbiased estimator to obtain estimates of the ratio $\lambda_{g} \equiv \frac{\sigma_{g}}{\sigma_{y^{*}}}$ and $\lambda_{z} \equiv \frac{a_{r} \sigma_{z}}{\sigma_{\tilde{y}}} \cdot{ }^{5}$ We impose these ratios when estimating the remaining model parameters (including $\sigma_{\tilde{y}}$ and $\sigma_{y^{*}}$ ) by maximum likelihood.

Our estimation method proceeds in sequential steps. In the first step, we follow Kuttner (1994) and apply the Kalman filter to estimate the natural rate of output, omitting the real rate gap term from equation (4) and assuming that the trend growth rate, $g$, is constant. We compute the exponential Wald statistic of Andrews and Ploberger (1994) for a structural break with unknown break date from the first difference of this preliminary estimate of the natural rate of output to obtain the median unbiased estimate of $\lambda_{g}$. In the second step, we impose the estimated value of $\lambda_{g}$ from the first step and include the real interest rate gap in the output gap equation under the assumption that $z$ is constant. We estimate the five model equations and apply the exponential Wald test for an intercept shift in the IS equation at an unknown date to obtain an estimate of $\lambda_{z}$.

In the final step, we impose the estimated values of $\lambda_{g}$ from the first step and $\lambda_{z}$ from the second step and estimate the remaining model parameters by maximum likelihood as described by Harvey (1989). ${ }^{6}$ Throughout, we impose the constraints that the slope $a_{r}$ of the IS equation is negative and the slope $b_{y}$ of the Phillips curve is positive. We view these as minimal priors on the structure of the model that, in the event, facilitate the convergence of the numerical optimization during estimation. We compute confidence intervals and corresponding standard errors for the estimates of the states using Hamilton's

\footnotetext{
${ }^{5}$ Substituting (6) into (4), the latter can be written as

$$
\tilde{y}_{t}=a_{y, 1} \tilde{y}_{t-1}+a_{y, 2} \tilde{y}_{t-2}+\frac{a_{r}}{2}\left(r_{t-1}+r_{t-2}-\left(g_{t-1}+g_{t-2}\right)\right)-\frac{a_{r}}{2}\left(z_{t-1}+z_{t-2}\right)+\epsilon_{\tilde{y}, t}
$$

The ratio $\lambda_{z}$ based on the test statistic for an intercept shift at an unknown date in this equation is thus the ratio of $a_{r} \sigma_{z}$ to $\sigma_{\tilde{y}}$.

${ }^{6}$ The vector of unobserved states in the first-stage estimation includes three lags of potential output; in the second stage it also includes one lag of $g$; and in the third stage, a second lag of $g$ plus two lags of $z$. We compute the conditional expectation and covariance matrix of the initial state, key inputs for the Kalman filter, as follows. For the lags of potential output, we apply the HP filter with $\lambda=36,000$ to log real GDP data starting four quarters prior to our estimation sample and take the values of the HP trend component for the three quarters prior to the sample start. For lags of $g$, we use the first difference of the HP trend. The component $z$ is initialized at 0 . We compute the covariance matrix of these states from the gradients of the likelihood function.
} 
(1986) Monte Carlo procedure that accounts for both filter and parameter uncertainty. ${ }^{7}$

\section{Estimation Results}

In this section, we report the model estimation results for the four economies. We start by discussing the parameter estimates and then turn to the resulting estimates of trend growth. The estimates of the natural rate of interest are discussed in the following section.

\subsection{Parameter Estimates}

Table 1 reports the estimation results for the four economies. For three of the economies, the sample spans 223 quarters from 1961:I to 2016:III, while data availability for the Euro Area dictates a sample start in 1972:I.

Focusing first on the estimates for the United States, the values for $\lambda_{g}$ and $\lambda_{z}$ indicate substantial time variation in trend growth and the natural rate of interest over the 56-year sample. For example, the estimates of the standard deviation of $\epsilon_{g}$ and the first difference of $r^{*}$ imply that the standard deviations of $g_{2016: I I I}-g_{1961: I}$ and $r_{2016: I I I}^{*}-r_{1961: I}^{*}$ are on the order of 1.8 percent and 2.9 percent, respectively (the results for both variables are expressed at annual rate). The 90 percent confidence interval for $\lambda_{g}$, computed by Monte Carlo simulations, ranges from 0.004 to $0.132 .{ }^{8}$

The slope coefficients $a_{r}$ and $b_{y}$ for the U.S. are reasonably large and precisely estimated, suggesting that both the output gap and the real rate gap are well identified. Nonetheless, even with hindsight, the natural rate of interest is estimated imprecisely, with a sample average standard error of 1.1 percentage points, as shown in the section of Table 1 labeled "S.E. (sample ave.)." The imprecision in estimates of the natural rate of interest is even greater when examining the one-sided estimates of $r^{*}$ that correspond more closely to "real-

\footnotetext{
${ }^{7}$ We draw the parameter vectors from a normal distribution with the covariance matrix of the parameter vector computed as the outer product of the gradients. During these draws, we impose in addition to the constraints $a_{r} \leq-0.0025$ and $b_{y} \geq 0.025$ the constraint that $a_{y, 1}+a_{y, 2}<1$. Discarding draws that violate either of these constraints reduces the width of the standard errors, substantially so for the Euro Area and the UK. The initial value of the state vector is drawn from a normal distribution with the mean and covariance given by the smoothed estimate of the initial state and its covariance matrix. Note that these estimated confidence intervals hold the imposed values of $\lambda_{g}$ and $\lambda_{z}$ fixed but take into account the uncertainty regarding $\sigma_{\tilde{y}}, \sigma_{\pi}$, and $\sigma_{y^{*}}$.

${ }^{8}$ To compute this confidence interval, we use parameter estimates based on the second-stage model with a time-varying trend growth and a constant natural rate of interest to construct 10,000 simulated series of $\left\{y_{t}^{*}, g_{t}\right\}$. For each pair of simulated series we compute the exponential Wald statistic for an intercept shift in the first difference of $y_{t}^{*}$.
} 
time" estimates, in that only current and past observations are used in estimating the state. (Because the full sample is used in estimating the model parameters, the analogy, however, is not exact.) The final observation standard errors shown at the bottom of the table, which provide a measure of the imprecision of one-sided estimates assuming the true values of $\lambda_{g}$ and $\lambda_{z}$ are known, are even wider.

Comparing parameter estimates across countries, the estimates of $\lambda_{g}$ indicate time variation in the trend growth rate, albeit at a smaller scale in the Euro Area and the UK. Even though the estimates of $\lambda_{z}$ are of similar magnitude across countries, the time variation of $r^{*}$ is magnified for the Euro Area and the UK by the smaller values of the slope parameter $a_{r}$ for these economies. Moreover, it is evident that the uncertainty around the natural rate estimates is closely related to the statistical significance of the slope parameters $a_{r}$ and $b_{y}$. For Canada, although $a_{r}$ is of similar magnitude as in the U.S. and is statistically significant, the fact that $b_{y}$ is both smaller and less precisely estimated implies that the average standard errors around $y^{*}$ and $r^{*}$ are larger than in the U.S. For the Euro Area, the slope of the IS equation is considerably flatter, and the average standard error for $r^{*}$ is very large, primarily driven by draws of the parameter vector in which $a_{r}$ is very close to zero and hence $r^{*}$ is barely identified. ${ }^{9}$

The parameter estimates for the UK are in several respects quite different from those for the other economies. Notably, the output gap is estimated to be much less persistent, as shown by the smaller value for $\sum a_{y}$, but inflation responds very strongly to these more transitory output gap fluctuations, with $b_{y}$ being about ten times the size compared to its value for the other three economies. By contrast, this output gap estimate seems to bear little relation to the real rate gap, with $a_{r}$ estimated to be close to zero. Inflation also seems to be less well explained by its own lags and the lagged output gap, as shown by the very large standard deviation $\sigma_{\pi}$.

It is important to stress that the estimates of the unobserved variables - the level of potential output, the trend growth rate of potential output, and the natural rate of interest - are imprecisely estimated, as seen in the lower portion of Table 1. This imprecision reflects both the "standard" uncertainty associated with estimated parameters that would obtain

\footnotetext{
${ }^{9}$ The fact that more probability mass of the distributions of $a_{r}$ and $b_{y}$ is located close to zero is also reflected in the number of draws during the computation of the standard errors that are being rejected because they violate the constraints $a_{r} \leq-0.0025$ and $b_{y} \geq 0.025$. While only about 2 percent of draws are rejected for the US, about 15 percent are rejected for the UK, 20 percent for the Euro Area, and 25 percent are rejected for Canada.
} 
even if these variables were assumed to be constant, as well as the uncertainty associated with time-variation in these variables. The imprecision is particularly pronounced in the cases of the natural rate of interest in the Euro Area and the United Kingdom, where the error bands are very wide reflecting the imprecision of the estimate of the slope coefficient, $a_{r}$, in the output gap equation.

\subsection{Estimates of the Output Gap and Trend GDP Growth}

The upper panels of Figure 1-4 show the filtered (one-sided) estimates of the output gap for the four economies. The shaded regions indicate the periods of recessions for each economy. ${ }^{10}$ With a few exceptions, large downward movements in estimated output gaps generally conform to the timing of recessions. All four economies experience negative output gaps following the global financial crisis. However, output gaps after the crisis are generally less negative (or more positive) than some other estimates (for example, the International Monetary Fund 2015). The subdued declines in estimated output gaps in our model likely reflects the relatively modest falloff in core inflation in the four economies, which in the context of the model is at odds with the presence of large negative output gaps (Laubach and Williams 2016).

The upper panels of these four figures show the estimated real interest rate gap - the difference between the ex ante real interest rate and the filtered estimate of the natural rate of interest. Consistent with the model structure, following periods when the real rate gap is positive, the estimated output gap tends to be declining; when real rate gaps are negative, the output gap tends to be rising.

A striking finding common to all four economies is the secular downward trend in the estimated trend growth rates of output over the past 25 years. This process appeared to accelerate in the final part of the sample, with trend potential output growth slowing by a percentage point on average over 2007-2016. Except for the Euro Area, these declines are concentrated in the 2008-09 period of the global financial crisis and its aftermath, as shown by the dashed lines in the lower panels of Figures $1-4$. In these three regions, trend growth has remained relatively stable at its new lower level since 2010. In contrast, estimated trend growth in the Euro Area fell by a relatively modest amount during the global financial crisis,

\footnotetext{
${ }^{10}$ The following sources are used for recession dating in the figures United States: National Bureau of Economic Research; Canada and the United Kingdom: Economic Cycle Research Institute; Euro Area: CEPR Euro Area Business Cycle Dating Committee.
} 
but has been on a steady downward trajectory following the onset of the Euro crisis.

The estimated declines in trend GDP growth over the past decade are broadly consistent with, but often somewhat larger than, estimates by other economists. Table 2 reports the estimated trend growth rate of potential output for the years 1990, 2007, and 2016, as well as estimates of long-run growth from alternative sources. In the case of the United States, our 2016 estimate of trend growth of 1.5 percent is lower than that of professional forecasters, but in line with the estimates by the International Monetary Fund (2016) and Fernald (2016). It is also close to the most recent median projection of 1.8 percent by the Federal Open Market Committee (Board of Governors of the Federal Reserve System 2016). Our 2016 estimate for trend growth of 1.5 percent in Canada is essentially identical to that from the Bank of Canada (Agopsowicz et al. 2016, Bank of Canada 2016), but about $1 / 2$ percentage point below estimates by the IMF and professional forecasters. Our 2016 estimate of trend growth for the Euro Area of only 1.1 percent is between 1/4 and 1/2 percentage points below the long-run forecasts from the IMF and professional forecasters. Finally, our trend growth forecast for the United Kingdom of 1.9 percent is close to that of the IMF and slightly below that of professional forecasters.

This pattern of declining trend GDP growth in advanced economies is consistent with alternative estimates based on methodologies that decompose potential output into its component parts (see Fleischman and Roberts, 2011; Congressional Budget Office, 2016; and International Monetary Fund 2015). These analyses highlight the roles of slowing labor force growth due to demographics and a slowdown in trend productivity growth. The productivity slowdown in the United States is documented by Byrne et al. (2016), Fernald (2016), and Gordon (2016), and the European productivity slowdown is analyzed in Cette et al. (2016).

\subsection{Estimated Natural Rates of Interest}

Although the estimated natural rates of interest differ across economies owing to idiosyncratic influences, all exhibit two phases of significant and sustained declines over the past quarter century: First, a moderate secular decline over 1990-2007, and second, a more substantial decline since 2007. These are seen in the lower panels of Figures 1-4 and in Table 3, which reports the annual averages of the natural rate estimates for the three years 1990, 2007, and 2016. In 1990, the estimates range between about $2-1 / 2$ and $3-1 / 2$. In each 
case, the estimates are lower in 2007, on the eve of the global financial crisis, ranging from roughly 2 to $2-1 / 2$ percent. In Canada and the Euro Area, this initial decline is more than fully accounted for by the estimated decline in the trend growth rate of potential output, as reported in Table 2. For the United States and the United Kingdom, declines in both trend growth of potential output, $g$, and the random walk factor, $z$, contribute to the decline in the estimated natural rate over this period.

Estimated natural rates of interest plummeted for all four regions in the immediate aftermath of the global financial crisis (Figures 1-4). Estimates for Canada and the United States then edged down further over 2010-2016, and are close to all-time lows at the end of our sample. In contrast to the results for Canada and the United States, natural rate estimates for the Euro Area and the United Kingdom rebounded in 2010, but then fell sharply again following the Euro crisis. In Canada, the United States, and the United Kingdom, most of the overall decline in the natural rate from 2007 to 2016 is accounted for by a drop in the estimated trend growth rate. In the Euro Area, declining trend growth accounts for less than half of the overall fall in the natural rate of interest.

This pattern of a secular decline in real interest rates is seen in market-based measures and survey data as well. As discussed in Laubach and Williams (2016) and reported in Table 3, yields on inflation-protected Treasury securities and surveys of economists display a sustained downward trend in the United States. We do not have a consistent time series of long-run forecasts for interest rates in the other regions. However, for Canada, the Euro Area, and the United Kingdom, real yields five to ten years ahead show significant declines as well. Because these market-measures embed time-varying risk and liquidity premiums, we caution against ascribing too much weight to the specific numbers and focus more broadly on the overall direction.

\subsection{Robustness}

Estimates of the natural rate of interest are inherently imprecise and potentially sensitive to model specification. A number of papers have explored the sensitivity of estimates of the natural rate of interest to alternative specifications. Despite substantial differences in model specification and methodology, this research consistently finds strong evidence of a sizable decline in the natural rate of interest over the past 25 years, with estimates reaching historically low levels in recent years. 
Our natural rate estimates for the United States have been shown to be robust to alternative specifications for the inflation process and expected inflation (Laubach and Williams; 2003, 2015). Lubik and Matthes (2015) explore a much more flexible specification of inflation and output in their VAR model. Their model allows for time-variation in all model parameters and thereby allows for shifts in monetary policy regimes and other structural changes in the economy. Their estimates of the natural rate display a large decline over the past decade, reaching roughly zero in 2016. Johannsen and Mertens (2016) develop a model that combines macroeconomic data with data from the yield curve and also find that the natural rate of interest has fallen significantly over the past decade, although their point estimate for 2016 of 0.7 is slightly higher than ours. Estimates of the natural rate from dynamic stochastic general equilibrium (DSGE) models that explicitly incorporate forward-looking behavior in output and inflation display a marked decline over the past decade and continuing very low levels. Although direct comparison between DSGE model estimates and ours is complicated by the fact that the DSGE concept of the natural rate is a period-by-period measure of the real rate that would occur absent nominal frictions, while ours is a medium- or longer-run concept, one can usefully compare our estimates to the medium-run forecast of real natural rates rates generated by a DSGE model. The model forecasts of the natural rate over the next five years from the DSGE model of Del Negro et al. (2014) track our estimates reasonably closely over the past 30 years (see also Cúrdia, 2015).

Although there has not been as much research assessing alternative estimates of the natural rate of interest for the other three regions, the existing studies also find a significant drop in the natural rate in recent years. Mendes (2014) examines a number of methods of estimating the natural rate in Canada and places it in the range of 1-2 percent in 2015, while the Bank of Canada (2016) reports a range of between 0.75 and 1.75 percent. Our estimate is in the center of that range. Goldby et al. (2016) report estimates of the natural rate in the United Kingdom using the Bank of England's DSGE model. Similar to the DSGE model evidence for the United States, they find a sizable decline in the natural rate in the United Kingdom following the global financial crisis. Their DSGE model's forecast for the natural rate over the next five years is 1.6 percent in 2016, close to our estimate of 1.5 percent. Constâncio (2016) reports estimates of the natural rate in the Euro Area based on Mésonnier and Renne's (2007) version of the Laubach-Williams (2003) model, a 
Bayesian VAR, and a DSGE model. All three models display large declines in the estimated natural rate, reaching levels near or below zero at the end of the sample, consistent with our findings.

\section{Global and Local Determinants of the Natural Rate}

In this section, we investigate the interdependence of natural rates of interest across the four economies we study. As discussed earlier, economic theory implies that movements in natural rate of interest should be correlated across countries. Although such cross-country linkages were not imposed in estimation, there is evidence of substantial comovement of the estimates of both the natural rate of interest and the trend growth rate of output over time. We explore this interdependence using vector error-correction (VECM) models.

\subsection{Correlations of Natural Rates Across Regions}

The preceding discussion highlighted the downward movements in natural rate estimates over the past 25 years. In this section, we explore more formally the comovement of natural rate estimates over the full sample for which we have estimates for all four economies (1972-2016). As discussed previously, natural rates are assumed to be nonstationary in our model, and standard augmented Dickey-Fuller tests confirm this, as shown in the upper part of Table 4. Given this nonstationarity, we cannot use methods that require stationarity, such as correlations or principal components, to describe natural rate comovement over time. Instead, we characterize the joint movement in natural rate estimates using a simple VECM model. Because the natural rates are themselves generated regressors from the estimated model, care should be taken in interpreting these results and their statistical significance. Instead, this analysis should be viewed as a simple way to describe the comovement evident in the estimates, without putting much credence to the specific numerical results or inference.

With that caveat in mind, there is evidence of a single cointegrating vector linking the four natural rates series based on a standard Johansen test. The estimated cointegrating vector is reported in the middle portion of Table 4. Based on lag tests, a VECM model with eight lags is estimated and the key results are reported in the table. The VECM estimates suggest that natural rates comove over time, but are also subject to idiosyncratic influences. 
To summarize the interdependence in natural rates, Figure 5 shows variance decompositions for each natural rate process in terms of shocks to the four natural rates, using a Cholesky decomposition with ordering: Canada, UK, Euro Area, and the United States. Although the specific values of the variance decompositions are sensitive to the ordering of the regions, the overall finding of substantial comovement in the estimated natural rates of interest is robust.

The variance decompositions indicate the presence of a great deal of interdependence in natural rates across economies. For example, shocks to the US natural rate contribute about 35 percent to natural rate variation in Canada at a 10-year horizon. Shocks to natural rates in the Euro Area and the UK play a smaller role, but still have a nontrivial effect on the natural rate in Canada at long horizons. A similar pattern is seen in the Euro Area, where US natural rate shocks are a major source of natural rate variance at long horizons, while shocks in the UK have a smaller, but still noticeable effect; in the UK, shocks to the natural rates in the US and Euro Area are a substantial source of variance as well. The estimated natural rate in the US is less dependent on those in other regions; however, it is not completely independent, with around 20 percent of the long-horizon variance emanating from other economies.

Because the divergences implied by our single cointegrating vector are somewhat puzzling in a world of high capital mobility, we also present results from a VECM in which we impose three cointegrating vectors in the lower portion of Table 4 . The variance decompositions for each natural rate process, shown in Figure 6, again indicate interdependence in natural rates. For the Euro Area and the UK, variance in the natural rate of the home economy is affected by shocks to the other three economies in similar magnitudes as to in the model with a single cointegrating vector. Shocks to the natural rates in Canada and the Euro Area are a larger source of natural rate variance in the US under the VECM with three cointegrating vectors, but the US remains less dependent on other regions. The variance decomposition for Canada indicates relatively less dependence on natural rates in other economies.

We also find evidence of comovement in the estimates of trend output growth across the four economies. Table 5 reports the results of augmented Dickey-Fuller and cointegration tests for the model estimates of trend GDP growth, as well as results from a VECM with a single cointegrating vector and one with three cointegrating vectors imposed. The results 
from both of the estimated VECM models for trend growth rates indicate the presence of interdependence across countries. The resulting patterns in variance decompositions are shown in Figures 7 and 8. With the exception of the UK, they are similar to those for the natural rates of interest. This finding is not entirely surprising since movements in trend output growth are a major source of time variation in natural rates of interest in our model.

Overall, these results point to the potential for formally incorporating a global factor in the analysis of trend output growth and the natural rate of interests across countries. Such an approach is also supported by the evidence of a global factor influencing asset prices across countries, described by Miranda-Agrippino and Rey (2015). We leave the explicit modeling and estimation of global and local factors for trend growth rates and natural rates of interest to future work.

\section{Conclusion}

In this paper, we estimated the natural rates of interest and output and the trend growth rate of output in four economies - Canada, the Euro Area, the United Kingdom, and the United States - using a version of the Laubach-Williams (2003) model. Our findings mirror those for the United States from earlier research: estimated natural rates of interest exhibit significant variation over time, movements in the trend growth rate are an important determinant of changes in the natural rate, and natural rates of interest have declined over the past quarter century, reaching historically low levels in the most recent past. In addition, and again consistent with past research, natural rate estimates tend to be highly imprecise.

These findings suggest that declining natural rates of interest are an international phenomenon and therefore stem in large part from developments common to many countries, rather than idiosyncratic national factors. This argues for more research that takes an international perspective in analyzing natural rates, by including data from economies besides the United States and by examining structural changes that influence natural rates across the globe. In addition, research using alternative model specifications more suited for each economy's features may yield more precise estimates and insights into the robustness of our results to alternative approaches.

Finally, as discussed in Laubach and Williams (2016), very low natural rate of interest, if sustained into the future, have profound implications for monetary policy (see also 
Blanchard, Dell'Ariccia, and Mauro, 2010; Summers 2014). All else equal, a lower average real interest rate in turn implies that episodes of monetary policy being constrained at the effective zero lower bound are likely to be more frequent and longer. Moreover, our finding that natural rates have declined in a number of major advanced economies suggests that this is not a problem unique to the United States, but has broader consequences globally. For example, as discussed in Eggertsson et al. (2015), in an environment of a very low natural rate of interest, the effects of the lower bound on interest rates are amplified and international spillovers and the benefits from international policy coordination may increase. 


\section{References}

Agopsowicz, Andrew, Dany Brouillette, Shutao Cao, Natalia Kyui and Pierre St-Amant. 2016. "April 2016 Annual Reassessment of Potential Output in Canada," Bank of Canada Staff Analytical Note 2016-4, April 2016.

Andrés, Javier, J. David López-Salido and Edward Nelson. 2009. "Money and the natural rate of interest: Structural estimates for the United States and the euro area," Journal of Economic Dynamics and Control, 33, 758-776.

Andrews, Donald, and Werner Ploberger. 1994. "Optimal Tests When a Nuisance Parameter Is Present Only Under the Alternative," Econometrica, 62, 1383-1414.

Bank of Canada. 2016. "Monetary Policy Report," April 2016.

Barsky, Robert, Alejandro Justiniano, and Leonardo Melosi. 2014. "The Natural Rate of Interest and Its Usefulness for Monetary Policy," American Economic Review: Papers E Proceedings, 104(5), 37-43.

Bernanke, Ben S. 2005. "The Global Saving Glut and the U.S. Current Account Deficit," Board of Governors of the Federal Reserve System, April 14, 2005.

Blanchard, Olivier, Giovanni Dell'Ariccia, and Paolo Mauro. 2010. "Rethinking Macroeconomic Policy," IMF Staff Position Note SPN/10/03.

Board of Governors of the Federal Reserve System. 2016. "Minutes of the Federal Open Market Committee, September 2021, 2016."

Byrne, David M., Marshall B. Reinsdorf, and John G. Fernald. 2016. "Does the United States have a Productivity Slowdown or a Measurement Problem?" Federal Reserve Bank of San Francisco Working Paper 2016-03.

Cette, Gilbert, John G. Fernald, and Benoit Mojon. 2016. "The Pre-Great Recession Slowdown in Productivity," Federal Reserve Bank of San Francisco Working Paper 2016-08.

Congressional Budget Office. 2014. "The 2014 Long-Term Budget Outlook." July 2014.

Congressional Budget Office. 2016. "The Budget and Economic Outlook: 2016 to 2026." January 2016. 
Constâncio, Vítor. 2016. "The challenge of low real interest rates for monetary policy," Macroeconomics Symposium at Utrecht School of Economics, 15 June 2016.

Council of Economic Advisers. 2015. "Long-Term Interest Rates: A Survey," July 2015.

Cúrdia, Vasco, Andrea Ferrero, Ging Cee Ng, and Andrea Tambalotti. 2015. "Has U.S. Monetary Policy Tracked the Efficient Interest Rate?" Journal of Monetary Economics, $70,72-83$.

Cúrdia, Vasco. 2015. "Why So Slow? A Gradual Return for Interest Rates," Federal Reserve Bank of San Francisco Economic Letter, 2015-32, October 13, 2015.

Del Negro, Marco, Marc Giannoni, and Frank Schorfheide. 2015. "Inflation in the Great Recession and New Keynesian Models", American Economic Journal: Macroeconomics, 7(1), January, 168-96.

Edge, Rochelle M., Thomas Laubach, and John C. Williams. 2007. "Learning and Shifts in Long-Run Productivity Growth," Journal of Monetary Economics, November, 24212438 .

Eggertsson, Gauti B., Neil R. Mehrotra, Sanjay R. Singh, and Lawrence H. Summers. 2015. "A Contagious Malady? Open Economy Dimensions of Secular Stagnation," Brown University, November 20, 2015.

Fagan, Gabriel, Jerome Henry, and Ricardo Mestre. 2001. "An Area-Wide Model (AWM) for the Euro Area," European Central Bank Working Paper Series No. 42, January.

Fernald, John G. 2016. "Reassessing Longer-Run U.S. Growth: How Low?" Federal Reserve Bank of San Francisco Working Paper 2016-18, AUgust 2016.

Fleischman, Charles A., and John M. Roberts. 2011. "From Many Series, One Cycle: Improved Estimates of the Business Cycle from a Multivariate Unobserved Components Model," Finance and Economics Discussion Series Divisions of Research \& Statistics and Monetary Affairs Federal Reserve Board, Washington, D.C. 2011-46.

Fujiwara, Shigeaki, Yuto Iwasaki, Ichiro Muto, Kenji Nishizaki, and Nao Sudo. 2016. "Developments in the Natural Rate of Interest in Japan," Bank of Japan Review, 2016-E-12, October 2016. 
Gagnon, Etienne, Benjamin K. Johannsen, and David Lopez-Salido. 2016. "Understanding the New Normal: The Role of Demographics," Finance and Economics Discussion Series 2016-080. Washington: Board of Governors of the Federal Reserve System, October 2016.

Galí, Jordi. 2008. Monetary Policy, Inflation, and the Business Cycle: An Introduction to the New Keynesian Framework, Princeton, NJ: Princeton University Press.

Giammariou, Nicola, and Natacha Valla. 2003. "The Natural real rate of Interest in the Euro Area," European Central Bank Working Paper Series No. 233, May.

Goldby, Mike, Lien Laureys and Kate Reinold. 2015. "An estimate of the UK's natural rate of interest," Bank Underground (Bank of England blog), August 11, 2015.

Gordon, Robert J. 2016. The Rise and Fall of American Growth: The U.S. Standard of Living since the Civil War, Princeton: Princeton University Press.

Hall, Robert E. 2016, "Understanding the Decline in the Safe Real Interest Rate," Stanford Univerity, April 20, 2016.

Hamilton, James D. 1986. "A Standard Error for the Estimated State Vector of a StateSpace Model," Journal of Econometrics, 33, 387-397.

Hamilton, James D., Ethan S. Harris, Jan Hatzius, and Kenneth D. West. 2015. "The Equilibrium Real Funds Rate: Past, Present, and Future," presented at the US Monetary Policy Forum, New York, February 27, 2015.

Harvey, Andrew C. 1989. Forecasting, Structural Time Series Models and the Kalman Filter, Cambridge: Cambridge University Press.

International Monetary Fund. 2014. World Economic Outlook: Recovery Strengthens, Remains Uneven, Washington, DC, April.

International Monetary Fund. 2015. World Economic Outlook: Uneven Growth: Short- and Long-Term Factors, Washington, DC, April.

International Monetary Fund. 2016. World Economic Outlook: Too SLow for Too Long, Washington, DC, April.

Johannsen, Benjamin K., and Elmar Mertens. 2016. "A Time Series Model of Interest Rates with the Effective Lower Bound," Finance and Economics Discussion Series 2016-033. Washington: Board of Governors of the Federal Reserve System, April 2016. 
Juselius, Mikael, Claudio Borio, Piti Disyatat, and Mathias Drehmann. 2016. "Monetary Policy, the Financial Cycle and Ultra-low Interest Rates," Bank for International Settlements Working Paper No. 569, July.

Kahn, James A., and Robert W. Rich. 2007. "Tracking the new economy: Using growth theory to detect changes in trend productivity," Journal of Monetary Economics, 54, 16701701.

Kiley, Michael T. 2015. "What Can the Data Tell Us About the Equilibrium Real Interest Rate?" Finance and Economics Discussion Series 2015-077. Washington: Board of Governors of the Federal Reserve System, August 2015.

Kuttner, Kenneth. 1994. "Estimating Potential Output as a Latent Variable," Journal of Business and Economic Statistics, 12(3), July, 361-368.

Laubach, Thomas. 2009. "New Evidence on the Interest Rate Effects of Budget Deficits and Debt." Journal of the European Economic Association, 7(4), 858-885.

Laubach, Thomas, and John C. Williams. 2003. "Measuring the Natural Rate of Interest," Review of Economics and Statistics, 85(4), November, 1063-1070.

Laubach, Thomas, and John C. Williams. 2016. "Measuring the Natural Rate of Interest Redux," Business Economics, 51, 257-267.

Lubik, Thomas A., and Christian Matthes. 2015. "Calculating the Natural Rate of Interest: A Comparison of Two Alternative Approaches," Federal Reserve Bank of Richmond Economic Brief, October 2015, EB15-10.

Mendes, Rhys R. 2014. "The Neutral Rate of Interest in Canada," Bank of Canada Discussion Paper/Document danalyse 2014-5, September 2014.

Mésonnier, Jean-Stéphane, and Jean-Paul Renne. 2007. "A time-varying natural rate of interest for the euro area," European Economic Review, 51, 1768-1784.

Miranda-Agrippino, Silvia, and Hélène Rey. 2015. "World Asset Markets and the Global Financial Cycle," Bank of England, October 2015.

Neiss, Katherine S., and Edward Nelson. 2003. "The real interest-rate gap as an in?ation indicator," Macroeconomic Dynamics, 7, 239-262. 
Pescatori, Andrea, and Jarkko Turunen. 2015. "Lower for Longer: Neutral Rates in the United States," IMF Working paper 15/135, June 2015.

Rachel, Lukasz, and Thomas D Smith. 2015. "Secular Drivers of the Global Real Interest Rate," Bank of England Staff Working Paper No. 571, December.

Roberts, John M. 2001. "Estimates of the Productivity Trend using Time-Varying Parameter Techniques," Contributions to Macroeconomics, 1(1).

Stock, James H. 1994. "Unit Roots, Structural Breaks, and Trends," in R. Engle and D. MacFadden (eds.) 'Handbook of Econometrics,' Vol. 4, Amsterdam, Elsevier Science, $2739-2841$.

Stock, James, and Mark Watson. 1998. "Median Unbiased Estimation of Coefficient Variance in a Time-Varying Parameter Model," Journal of the American Statistical Association, 93, March, 349-358.

Summers, Lawrence H. 2014. "U.S. Economic Prospects: Secular Stagnation, Hysteresis, and the Zero Lower Bound," Business Economics, 49(2), 65-73.

Taylor, John B. 1993. "Discretion versus Policy Rules in Practice," Carnegie-Rochester Conference Series on Public Policy, 39, December, 195-214.

Wicksell, Knut. 1936. Interest and Prices (tr. of 1898 edition by R.F. Kahn). London: Macmillan.

Williams, John C. 2003. "The Natural Rate of Interest," Federal Reserve Bank of San Francisco Economic Letter, 2003-32, October 31, 2003.

Williams, John C. 2015. "The Decline in the Natural Rate of Interest," Business Economics, 50(2), 57-60, April.

Woodford, Michael. 2003. Interest and Prices: Foundations of a Theory of Monetary Policy, Princeton: Princeton University Press. 
Table 1: Parameter Estimates

\begin{tabular}{|c|c|c|c|c|}
\hline Parameter & United States & Canada & Euro Area & United Kingdom \\
\hline Sample & $1961-2016$ & $1961-2016$ & $1972-2016$ & $1961-2016$ \\
\hline$\lambda_{g}$ & 0.053 & 0.051 & 0.031 & 0.023 \\
\hline$\lambda_{z}$ & 0.030 & 0.025 & 0.040 & 0.024 \\
\hline$\sum a_{y}$ & 0.942 & 0.953 & 0.948 & 0.916 \\
\hline$a_{r}$ & $\begin{array}{r}-0.071 \\
(4.063)\end{array}$ & $\begin{array}{r}-0.067 \\
(2.874)\end{array}$ & $\begin{array}{r}-0.036 \\
(1.842)\end{array}$ & $\begin{array}{r}-0.009 \\
(1.682)\end{array}$ \\
\hline$b_{y}$ & $\begin{array}{c}0.079 \\
(3.136)\end{array}$ & $\begin{array}{c}0.044 \\
(1.618)\end{array}$ & $\begin{array}{c}0.065 \\
(1.760)\end{array}$ & $\begin{array}{c}0.490 \\
(2.064)\end{array}$ \\
\hline$\sigma_{\tilde{y}}$ & 0.354 & 0.353 & 0.290 & 0.110 \\
\hline$\sigma_{\pi}$ & 0.791 & 1.413 & 1.001 & 2.737 \\
\hline$\sigma_{y^{*}}$ & 0.575 & 0.631 & 0.400 & 0.878 \\
\hline$\sigma_{g}$ & 0.122 & 0.129 & 0.050 & 0.082 \\
\hline$\sigma_{z}$ & 0.150 & 0.131 & 0.323 & 0.287 \\
\hline$\sigma_{r^{*}}=\sqrt{\sigma_{g}^{2}+\sigma_{z}^{2}}$ & 0.194 & 0.184 & 0.327 & 0.299 \\
\hline \multicolumn{5}{|l|}{ S.E. (sample ave.) } \\
\hline$r^{*}$ & 1.072 & 1.555 & 3.943 & 3.336 \\
\hline$g$ & 0.402 & 0.449 & 0.240 & 0.417 \\
\hline$y^{*}$ & 1.504 & 2.383 & 1.676 & 0.876 \\
\hline \multicolumn{5}{|l|}{ S.E. (final obs.) } \\
\hline$r^{*}$ & 1.528 & 2.193 & 6.038 & 4.804 \\
\hline$g$ & 0.548 & 0.600 & 0.335 & 0.537 \\
\hline$y^{*}$ & 1.988 & 2.970 & 2.561 & 0.992 \\
\hline
\end{tabular}

Notes: $t$ statistics are in parentheses; $\sigma_{g}$ is expressed at an annual rate. 
Table 2: Trend Growth Estimates

\begin{tabular}{|c|c|c|c|c|c|}
\hline & \multirow[b]{2}{*}{1990} & \multirow[b]{2}{*}{2007} & \multirow[b]{2}{*}{$2016^{\dagger}$} & \multicolumn{2}{|c|}{ Change } \\
\hline & & & & $1990-2007$ & $2007-2016$ \\
\hline \multicolumn{6}{|l|}{ United States } \\
\hline HLW $g$ estimates & 3.3 & 2.8 & 1.5 & -0.6 & -1.3 \\
\hline Consensus Forecasts & 2.4 & 2.9 & 2.2 & 0.5 & -0.7 \\
\hline IMF World Economic Outlook & 2.6 & 3.1 & 1.8 & 0.5 & -1.3 \\
\hline Blue Chip Financial Forecasts & 2.5 & 2.9 & 2.2 & 0.4 & -0.7 \\
\hline \multicolumn{6}{|l|}{ Canada } \\
\hline HLW $g$ estimates & 3.5 & 2.5 & 1.5 & -1.0 & -1.0 \\
\hline Consensus Forecasts & 2.8 & 2.5 & 1.9 & -0.4 & -0.6 \\
\hline IMF World Economic Outlook & 3.2 & 2.7 & 2.0 & -0.5 & -0.7 \\
\hline \multicolumn{6}{|l|}{ Euro Area } \\
\hline HLW $g$ estimates & 2.7 & 2.1 & 1.1 & -0.6 & -1.0 \\
\hline Consensus Forecasts & $n / a$ & 2.0 & 1.3 & $n / a$ & -0.7 \\
\hline IMF World Economic Outlook & $n / a$ & 2.0 & 1.5 & $n / a$ & -0.6 \\
\hline \multicolumn{6}{|l|}{ United Kingdom } \\
\hline HLW $g$ estimates & 2.8 & 2.7 & 1.9 & -0.1 & -0.8 \\
\hline Consensus Forecasts & 2.5 & 2.5 & 2.1 & 0.0 & -0.5 \\
\hline IMF World Economic Outlook & 2.5 & 2.7 & 2.0 & 0.2 & -0.7 \\
\hline
\end{tabular}

Notes: Consensus Forecasts data are the mean of panellists' trend estimates of expected GDP growth in the 6 to 10 years following. IMF estimates are the 5-year ahead forecast for real GDP growth. Blue Chip estimates are the mean long-years ahead forecast for real GDP. For each of these three forecasts, numbers are the average of the Spring and Fall publications for each year. HLW estimates are yearly averages. Numbers may not sum due to rounding.

Sources: Consensus Economics Inc, London; IMF World Economic Outlook; Blue Chip Financial Forecasts. ${ }^{\dagger} 2016$ estimates are averages of the first three quarters. 
Table 3: Natural Rate Estimates

\begin{tabular}{|c|c|c|c|c|c|}
\hline & \multirow[b]{2}{*}{1990} & \multirow[b]{2}{*}{2007} & \multirow[b]{2}{*}{$2016^{\dagger}$} & \multicolumn{2}{|c|}{ Change } \\
\hline & & & & $1990-2007$ & $2007-2016$ \\
\hline \multicolumn{6}{|l|}{ United States } \\
\hline HLW $r^{*}$ estimates & 3.5 & 2.3 & 0.4 & -1.2 & -1.9 \\
\hline TIPS yields (5-10 years ahead) & $n / a$ & 2.5 & 0.8 & $n / a$ & -1.6 \\
\hline Blue Chip Financial Forecasts & 3.1 & 2.4 & 0.9 & -0.7 & -1.6 \\
\hline \multicolumn{6}{|l|}{ Canada } \\
\hline HLW $r^{*}$ estimates & 3.2 & 2.5 & 1.3 & -0.7 & -1.2 \\
\hline Real return bond yields ( $5-10$ years ahead) & $n / a$ & 2.0 & 0.4 & $n / a$ & -1.6 \\
\hline \multicolumn{6}{|l|}{ Euro Area } \\
\hline HLW $r^{*}$ estimates & 2.5 & 2.1 & -0.3 & -0.4 & -2.4 \\
\hline $\begin{array}{l}\text { French euro HICP-linked bond yields } \\
\text { ( } 5 \text {-10 years ahead) }\end{array}$ & $n / a$ & $n / a$ & 0.0 & $n / a$ & $n / a$ \\
\hline \multicolumn{6}{|l|}{ United Kingdom } \\
\hline HLW $r^{*}$ estimates & 2.9 & 2.6 & 1.5 & -0.3 & -1.1 \\
\hline Index-linked gilt yields (5-10 years ahead) & 4.4 & 1.5 & -0.9 & -2.9 & -2.4 \\
\hline \multicolumn{6}{|c|}{$\begin{array}{l}\text { Notes: All numbers are yearly averages. Blue Chip estimates are the difference in the mean long-years ahead } \\
\text { forecasts of the federal funds rate and CPI (average of the Spring and Fall publications). The Euro Area } \\
\text { securities are OAT€ bonds issued by Agence France Trésor and linked to the Euro Area harmonized inflation } \\
\text { index. Zero coupon yields are estimated for Canadian real return bonds. UK yields are calculated using } \\
\text { monthly average yields from the zero coupon real yield curve published by the Bank of England. Numbers } \\
\text { may not sum due to rounding. }\end{array}$} \\
\hline
\end{tabular}


Table 4: Cointegration: Natural Rate Estimates

\begin{tabular}{|c|c|c|c|c|}
\hline & United States & Canada & Euro Area & United Kingdom \\
\hline $\begin{array}{l}\text { ADF test (p-value) } \\
1961-2016 \\
1972-2016\end{array}$ & $\begin{array}{l}0.72 \\
0.90\end{array}$ & $\begin{array}{l}0.81 \\
0.68\end{array}$ & $\begin{array}{r}n / a \\
0.80\end{array}$ & $\begin{array}{l}0.16 \\
0.18\end{array}$ \\
\hline $\begin{array}{l}\text { Difference from US: } r_{U S}^{*}- \\
\text { Phillips-Perron test (p-value) } \\
\text { 1961-2016 } \\
\text { 1972-2016 }\end{array}$ & $r_{\text {Economy }}^{*}$ & $\begin{array}{r}<0.01 \\
0.06\end{array}$ & $\begin{array}{r}n / a \\
0.03\end{array}$ & $\begin{array}{l}0.28 \\
0.63\end{array}$ \\
\hline $\begin{array}{l}\text { VECM model with } 1 \text { cointegr } \\
\text { Cointegrating vector } \\
\text { (S.E.) }\end{array}$ & $\begin{array}{r}\text { ating vector } \\
1.00 \\
(-)\end{array}$ & $\begin{array}{c}-0.48 \\
(0.12)\end{array}$ & $\begin{array}{r}-0.65 \\
(0.12)\end{array}$ & $\begin{array}{r}-0.10 \\
(0.15)\end{array}$ \\
\hline $\begin{array}{l}\text { Error-correction coef. } \\
\text { (S.E.) }\end{array}$ & $\begin{array}{c}0.01 \\
(0.04)\end{array}$ & $\begin{array}{c}0.04 \\
(0.03)\end{array}$ & $\begin{array}{c}0.13 \\
(0.04)\end{array}$ & $\begin{array}{c}0.09 \\
(0.03)\end{array}$ \\
\hline $\begin{array}{l}\text { Granger lag test (p-value) } \\
\text { (8 lags) }\end{array}$ & 0.55 & 0.01 & 0.90 & $<0.01$ \\
\hline \multicolumn{5}{|c|}{ VECM model with 3 cointegrating vectors } \\
\hline $\begin{array}{l}\text { Cointegrating vectors } \\
\text { (S.E.) }\end{array}$ & $\begin{array}{r}1.00 \\
(-) \\
0.00 \\
(-) \\
0.00 \\
(-)\end{array}$ & $\begin{array}{r}0.00 \\
(-) \\
1.00 \\
(-) \\
0.00 \\
(-)\end{array}$ & $\begin{array}{r}0.00 \\
(-) \\
0.00 \\
(-) \\
1.00 \\
(-)\end{array}$ & $\begin{array}{c}-1.54 \\
(0.18) \\
-1.38 \\
(0.15) \\
-1.18 \\
(0.21)\end{array}$ \\
\hline $\begin{array}{l}\text { Error-correction coef., resp. } \\
\text { (S.E.) }\end{array}$ & $\begin{array}{c}<0.01 \\
(0.04) \\
0.02 \\
(0.04) \\
0.03 \\
(0.03)\end{array}$ & $\begin{array}{c}0.04 \\
(0.03) \\
-0.01 \\
(0.02) \\
-0.04 \\
(0.02)\end{array}$ & $\begin{array}{c}0.14 \\
(0.04) \\
-0.10 \\
(0.03) \\
-0.06 \\
(0.03)\end{array}$ & $\begin{array}{c}0.09 \\
(0.03) \\
-0.06 \\
(0.02) \\
-0.03 \\
(0.02)\end{array}$ \\
\hline $\begin{array}{l}\text { Granger lag test (p-value) } \\
\text { (8 lags) }\end{array}$ & 0.48 & 0.02 & 0.88 & $<0.01$ \\
\hline
\end{tabular}


Table 5: Cointegration: Trend Growth Estimates

\begin{tabular}{|c|c|c|c|c|}
\hline & United States & Canada & Euro Area & United Kingdom \\
\hline $\begin{array}{l}\text { ADF test (p-value) } \\
1961-2016 \\
1972-2016\end{array}$ & $\begin{array}{l}0.51 \\
0.88\end{array}$ & $\begin{array}{l}0.81 \\
0.66\end{array}$ & $\begin{array}{r}n / a \\
0.52\end{array}$ & $\begin{array}{l}0.11 \\
0.45\end{array}$ \\
\hline $\begin{array}{l}\text { Difference from US: } g_{U S}- \\
\text { Phillips-Perron test (p-value) } \\
\text { 1961-2016 } \\
\text { 1972-2016 }\end{array}$ & $g_{\text {Economy }}$ & $\begin{array}{r}<0.01 \\
0.45\end{array}$ & $\begin{array}{r}n / a \\
0.07\end{array}$ & $\begin{array}{l}0.14 \\
0.69\end{array}$ \\
\hline $\begin{array}{l}\text { VECM model with } 1 \text { cointegr } \\
\text { Cointegrating vector } \\
\text { (S.E.) }\end{array}$ & $\begin{array}{r}\text { ating vector } \\
1.00 \\
(-)\end{array}$ & $\begin{array}{c}0.14 \\
(0.16)\end{array}$ & $\begin{array}{r}-1.59 \\
(0.35)\end{array}$ & $\begin{array}{c}0.04 \\
(0.23)\end{array}$ \\
\hline $\begin{array}{l}\text { Error-correction coef. } \\
\text { (S.E.) }\end{array}$ & $\begin{array}{r}-0.03 \\
(0.03)\end{array}$ & $\begin{array}{c}0.04 \\
(0.02)\end{array}$ & $\begin{array}{c}0.05 \\
(0.02)\end{array}$ & $\begin{array}{c}0.01 \\
(0.02)\end{array}$ \\
\hline $\begin{array}{l}\text { Granger lag test ( } \mathrm{p} \text {-value) } \\
\text { (8 lags) }\end{array}$ & 0.01 & $<0.01$ & $<0.01$ & $<0.01$ \\
\hline \multicolumn{5}{|c|}{ VECM model with 3 cointegrating vectors } \\
\hline $\begin{array}{l}\text { Cointegrating vectors } \\
\text { (S.E.) }\end{array}$ & $\begin{array}{r}1.00 \\
(-) \\
0.00 \\
(-) \\
0.00 \\
(-)\end{array}$ & $\begin{array}{r}0.00 \\
(-) \\
1.00 \\
(-) \\
0.00 \\
(-)\end{array}$ & $\begin{array}{r}0.00 \\
(-) \\
0.00 \\
(-) \\
1.00 \\
(-)\end{array}$ & $\begin{array}{c}-1.30 \\
(0.08) \\
-1.48 \\
(0.16) \\
-1.02 \\
(0.06)\end{array}$ \\
\hline $\begin{array}{l}\text { Error-correction coef., resp. } \\
\text { (S.E.) }\end{array}$ & $\begin{array}{c}-0.04 \\
(0.03) \\
0.08 \\
(0.05) \\
<0.01 \\
(0.02)\end{array}$ & $\begin{array}{c}0.06 \\
(0.03) \\
-0.03 \\
(0.04) \\
-0.01 \\
(0.02)\end{array}$ & $\begin{array}{c}0.05 \\
(0.02) \\
-0.08 \\
(0.03) \\
0.01 \\
(0.01)\end{array}$ & $\begin{array}{c}0.02 \\
(0.02) \\
0.02 \\
(0.03) \\
-0.01 \\
(0.01)\end{array}$ \\
\hline $\begin{array}{l}\text { Granger lag test ( } \mathrm{p} \text {-value) } \\
\text { (8 lags) }\end{array}$ & $<0.01$ & 0.01 & $<0.01$ & $<0.01$ \\
\hline
\end{tabular}


Figure 1: Estimation Results for the US
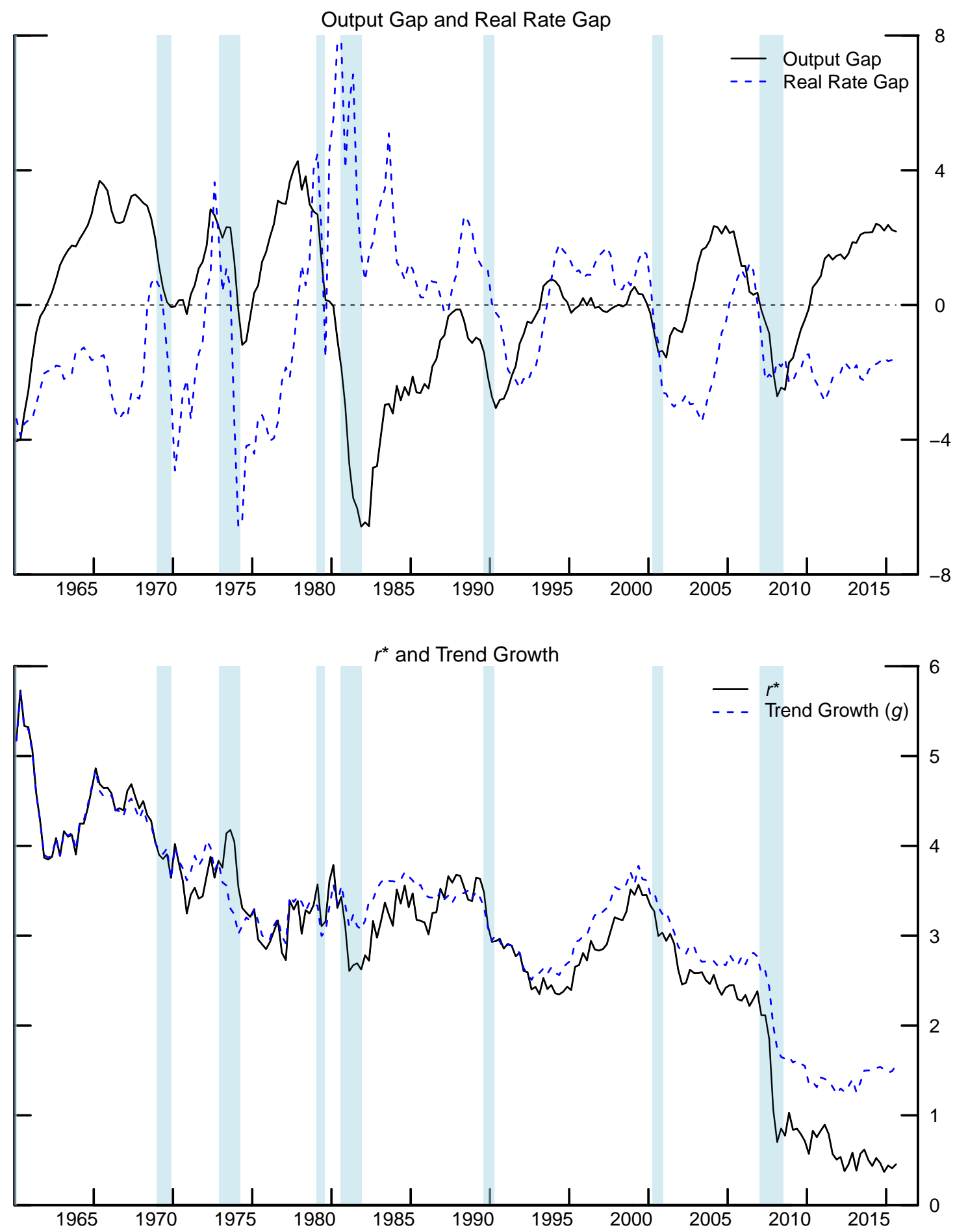
Figure 2: Estimation Results for Canada
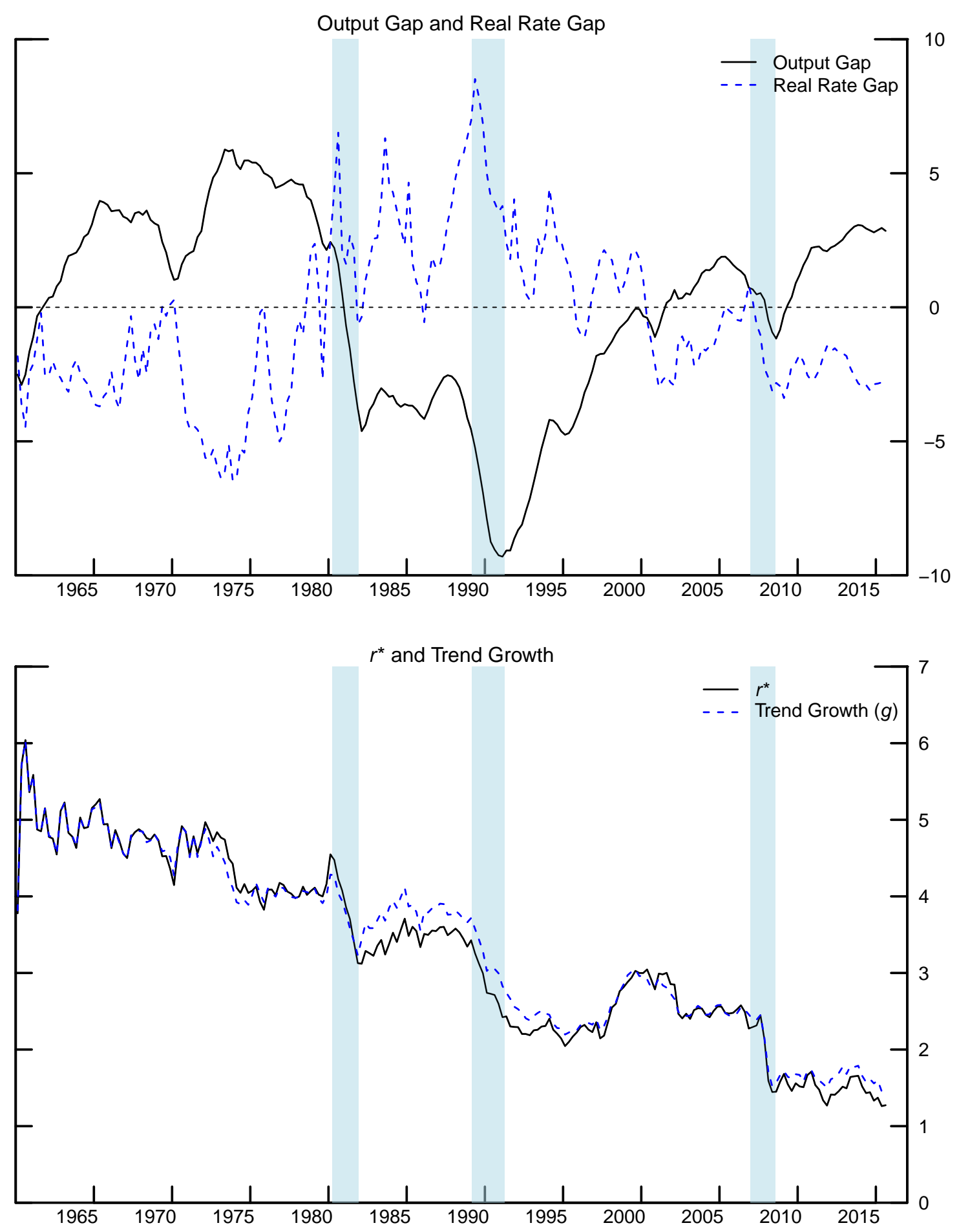
Figure 3: Estimation Results for the Euro Area
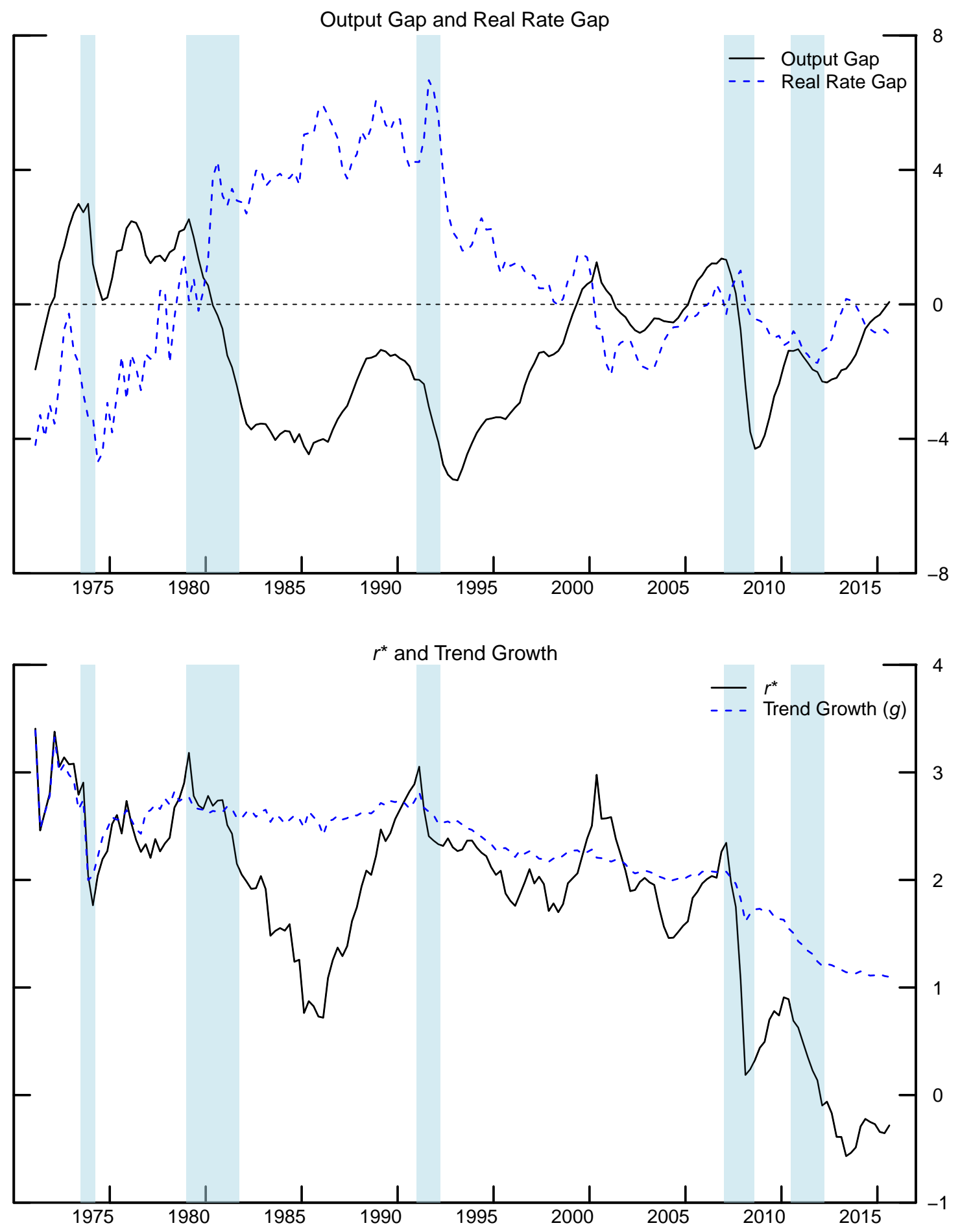
Figure 4: Estimation Results for the UK
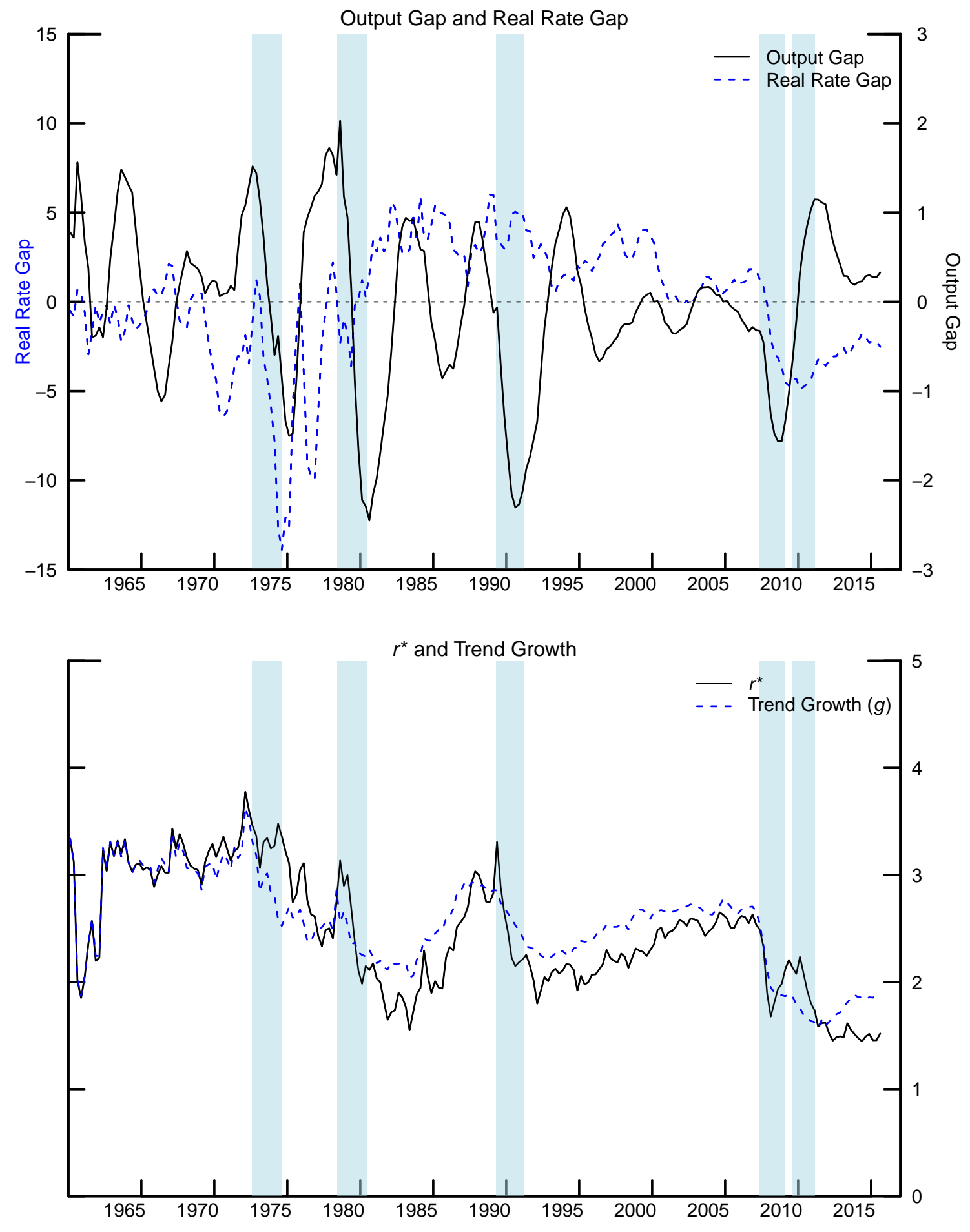
Figure 5: Variance Decompositions of Natural Rate Estimates:

VECM with One Cointegrating Vector
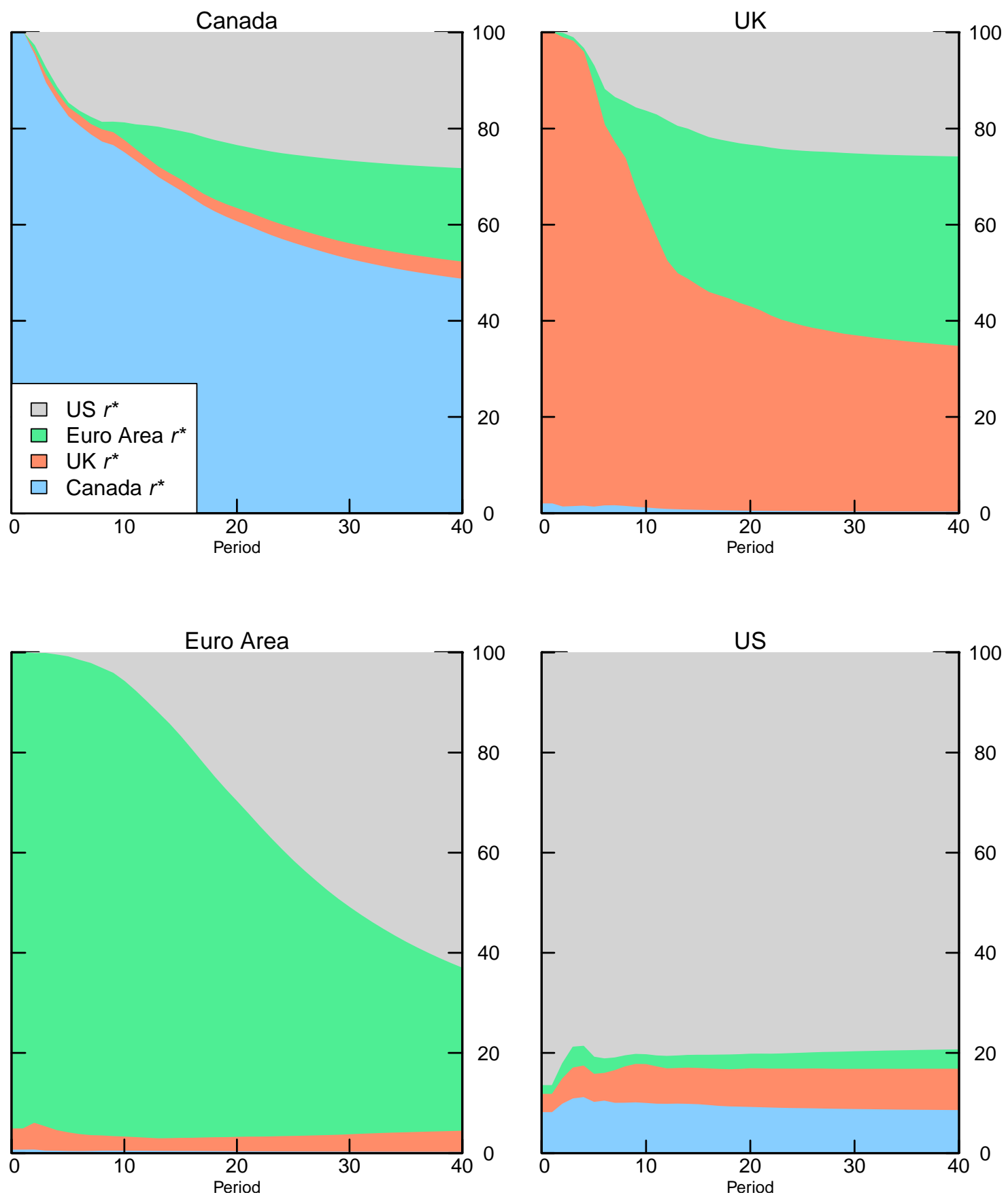
Figure 6: Variance Decompositions of Natural Rate Estimates: VECM with Three Cointegrating Vectors
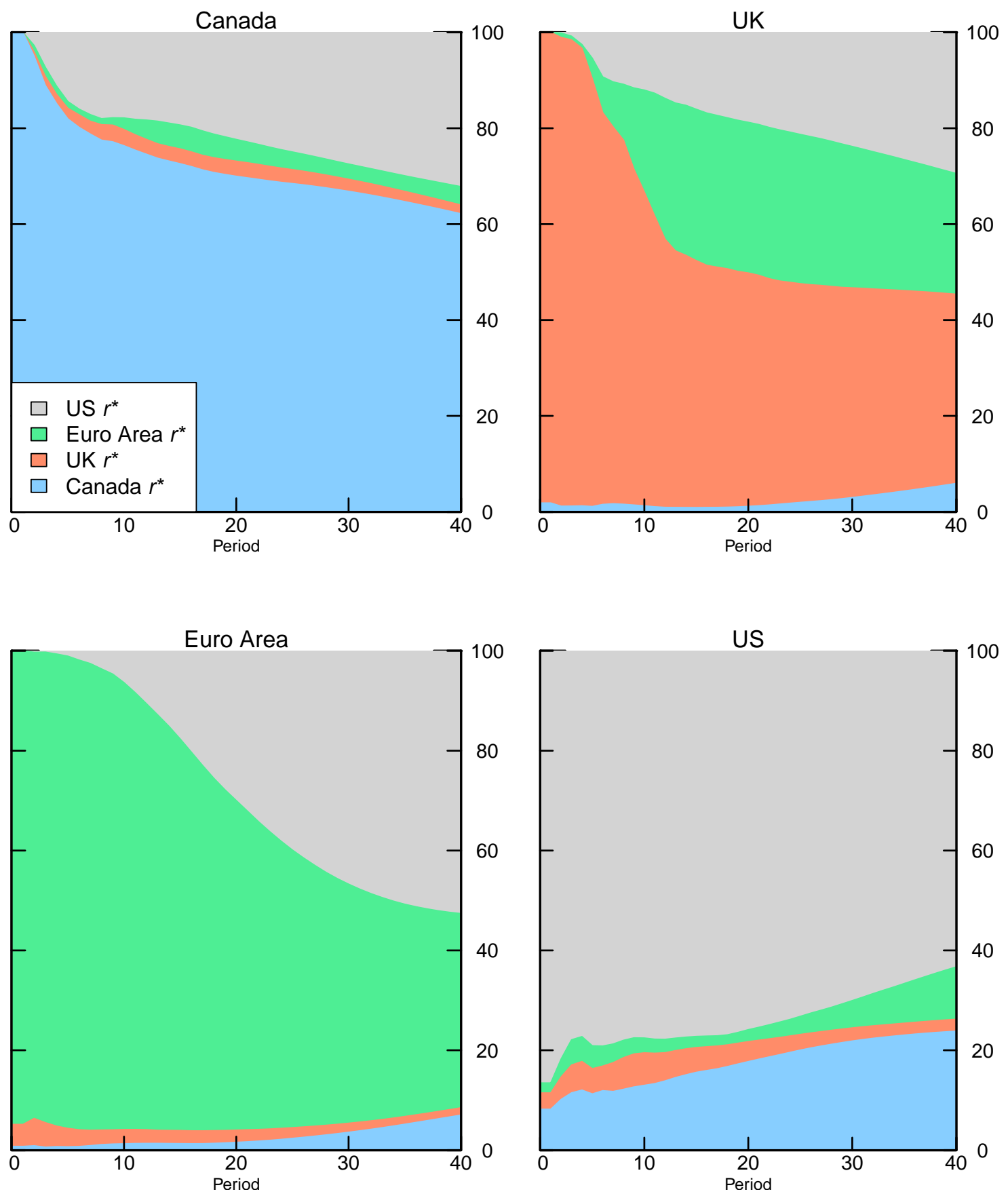
Figure 7: Variance Decompositions of Trend Growth Estimates:

VECM with One Cointegrating Vector
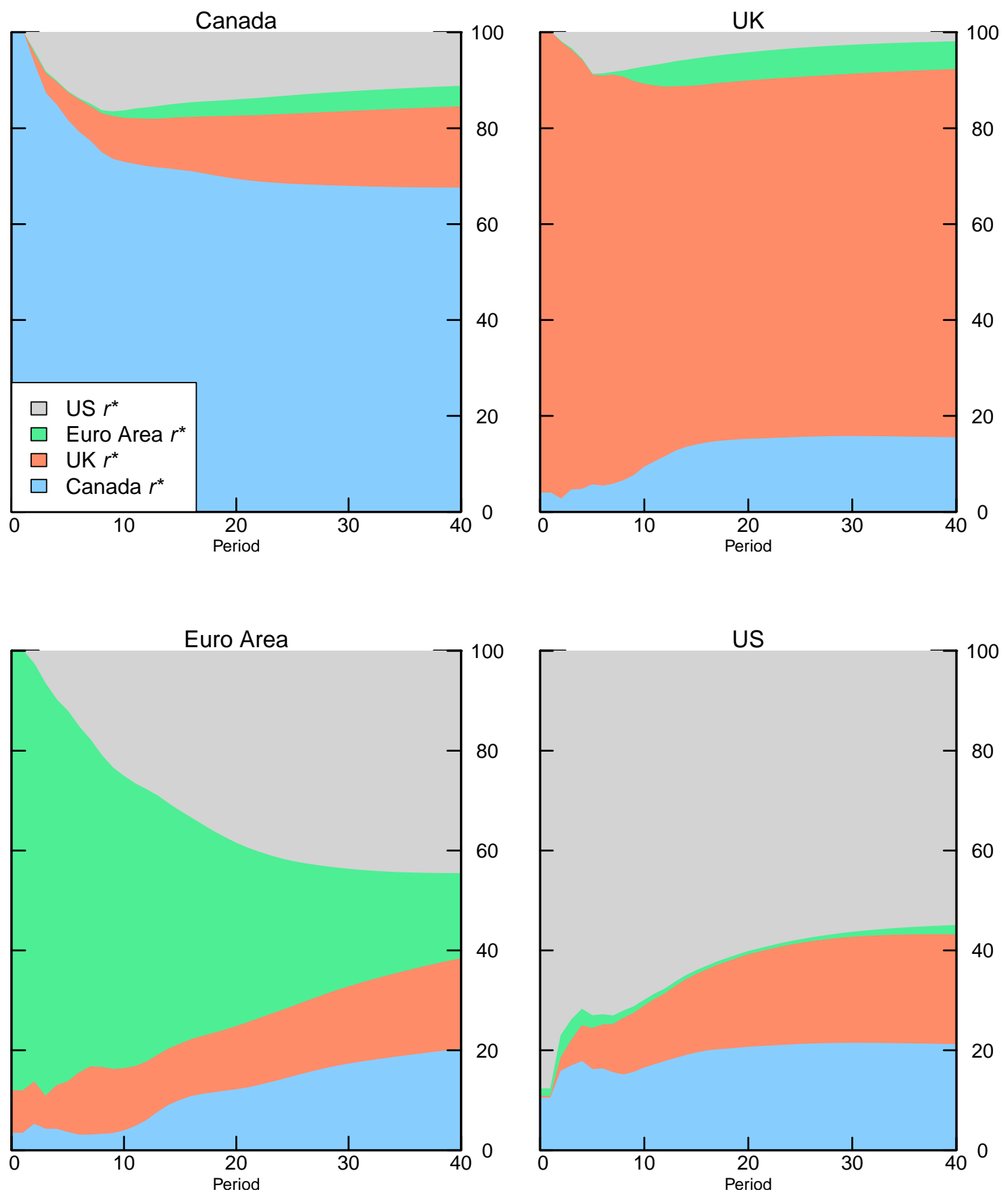
Figure 8: Variance Decompositions of Trend Growth Estimates:

VECM with Three Cointegrating Vectors
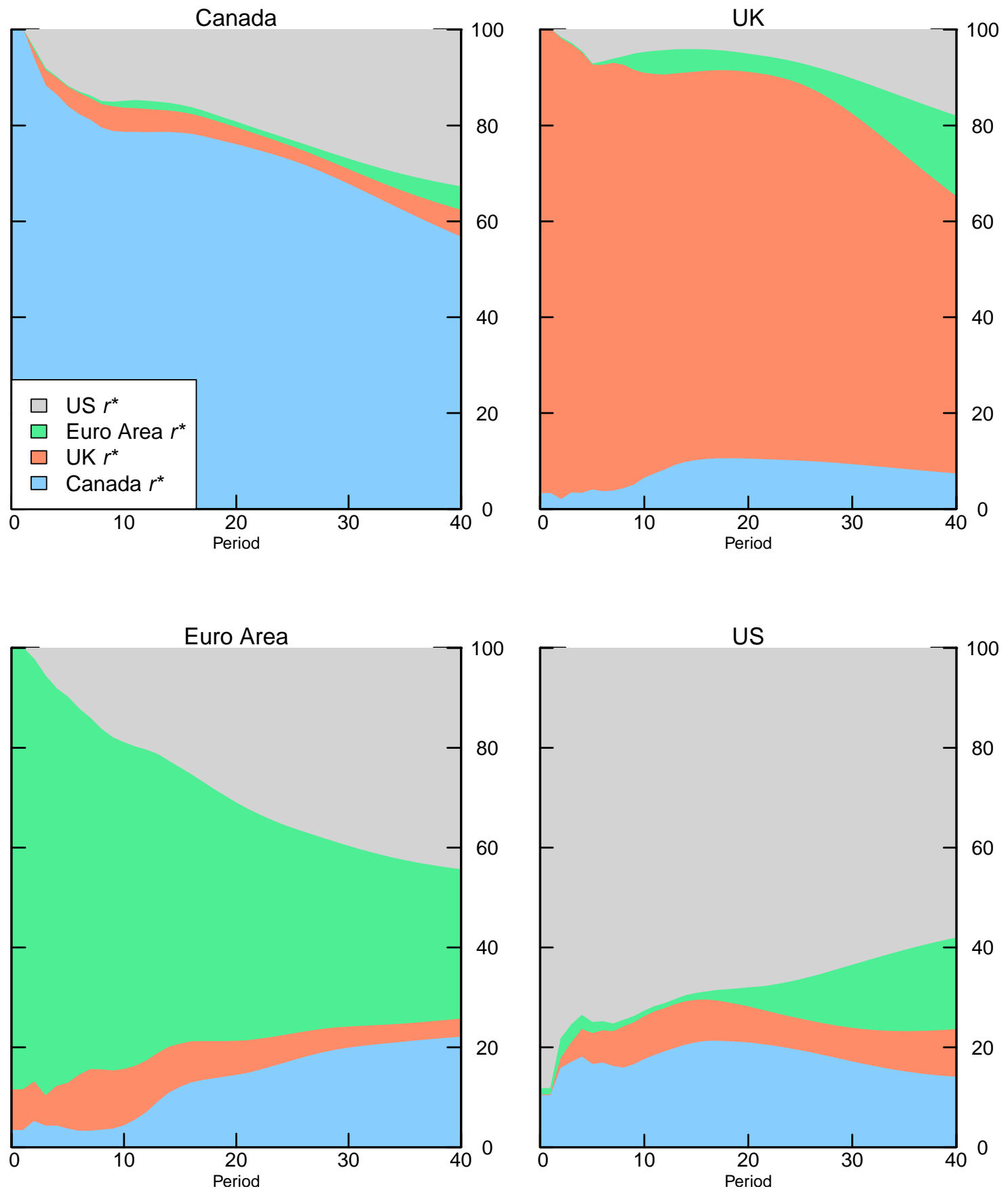


\section{Appendix: Data}

For each economy, we require data for real GDP, inflation, and the short-term nominal interest rate, as well as a procedure to compute inflation expectations to calculate the ex ante real short-term interest rate $r_{t}{ }^{11}$ The variable $y$ refers to the log of real GDP. The inflation measure is the annualized quarterly growth rate of the specified consumer price series. With the exception of the United States, for which core personal consumption expenditure (PCE) price data are available over the entire sample, the inflation series is constructed by splicing the core price index with an all-items price index. We use a four-quarter moving average of past inflation as a proxy for inflation expectations in constructing the ex ante real interest rate. Short-term interest rates are expressed on a 365-day annualized basis.

US inflation is constructed using the price index for PCE excluding food and energy, referred to as core PCE inflation. Real GDP and core PCE data are published by the BEA. The short-term interest rate is the annualized nominal funds rate, available from the Board of Governors, with the quarterly figure computed as the average of the monthly values. Because the federal funds rate frequently fell below the discount rate prior to 1965, we use the Federal Reserve Bank of New York's discount rate prior to 1965, reported by the IMF.

Canadian real GDP data is taken from the IFS. The short-term nominal interest rate is the Bank of Canada's target for the overnight rate, taken as the end-of-period value for each month and aggregated to quarterly frequency. Since the Bank of Canada began treating the target rate as its key interest rate in May 2001, we use the bank rate as the short-term interest rate prior to that date. We use the Bank of Canada's core Consumer Price Index to construct our inflation series. Prior to 1984, we use CPI containing all items. With the exception of real GDP, all data is from Statistics Canada.

UK real GDP data are taken from the Office of National Statistics. Our inflation measure is CPI excluding food and energy; prior to 1970 we use all-items CPI. Both are from the OECD. The short-term nominal interest rate is the Bank of England's Official Lending Rate, published by the Bank of England.

Euro Area data is from the Area Wide Model (Fagan et al., 2001). The inflation measure is HICP excluding energy; prior to 1988 we use overall HICP. The short-term interest rate is the three-month rate. We update the three series through 2016 using data from the ECB.

\footnotetext{
${ }^{11}$ A detailed description of our data and programs, as well as replication materials, is available on the Federal Reserve Bank of San Francisco's website.
} 
Figure 9: Comparison of Data across Economies

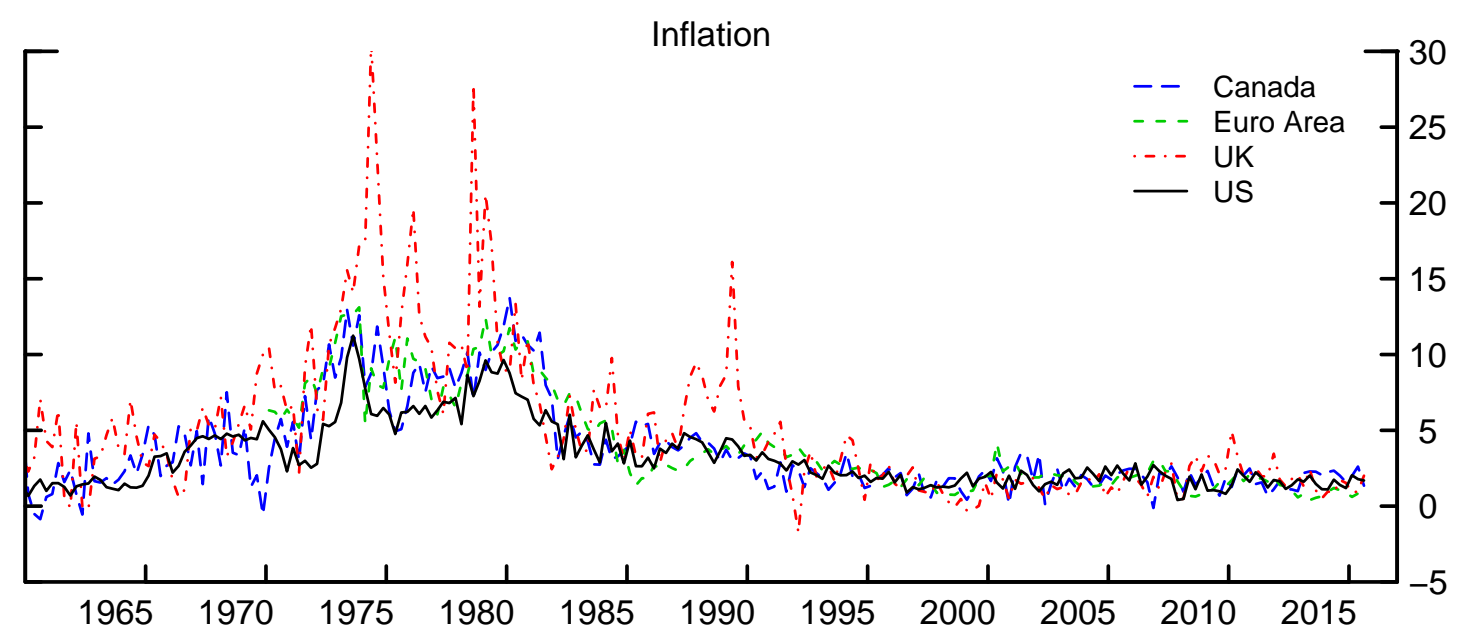

Log of Real GDP, HP Cycle Component
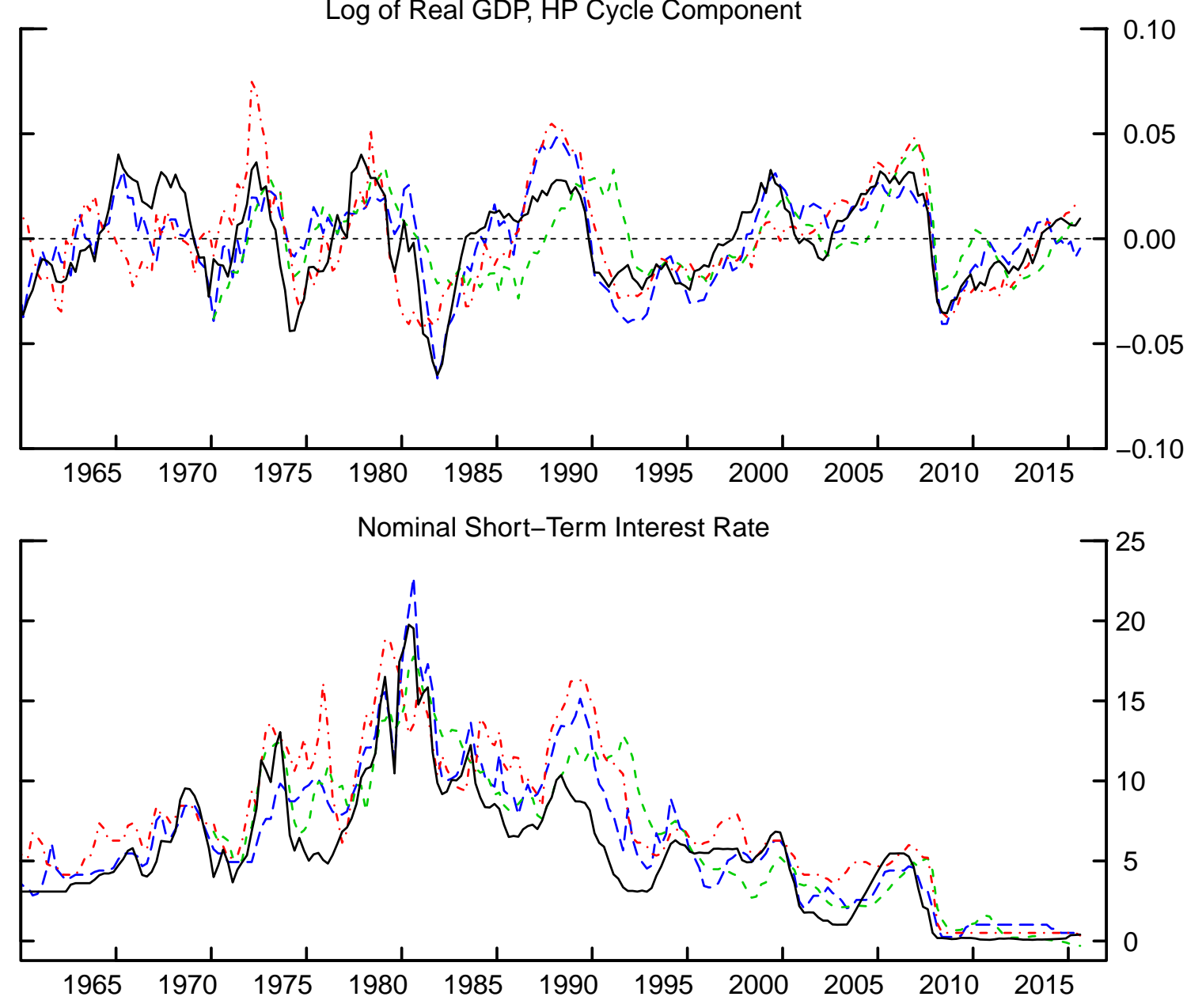


\section{Appendix: Comparison to Laubach and Williams (2003)}

In this appendix, we compare the estimates for the United States reported in this paper with real-time estimates generated using the Laubach-Williams (2003) model, which are reported on the Federal Reserve Bank of San Francisco's website. Figure 10 displays the filtered (one-sided) estimates of the output gap, trend growth of potential output, and the natural rate of interest, as well as the real rate gap generated using the ex-ante real short-term interest rate and the filtered natural rate estimates.

As shown in the upper panel, estimates of the output gap and real rate gap in this paper largely resemble estimates from the LW (2003) model. In general, the trend growth and natural rate estimates exhibit similar movements across both models, with the recent decline in the natural rate occurring simultaneously across both sets of estimates. More of the recent decline in the natural rate is accounted for by a decline in trend growth in the estimates from this paper than in estimates from the Laubach-Williams model.

One departure in this paper from the Laubach-Williams (2003) methodology is the method for calculating a measure of inflation expectations, which we use to determine the real short-term interest rate as described in the Data Appendix. While the LaubachWilliams (2003) model uses a univariate $\operatorname{AR}(3)$ of inflation estimated over the past 40 quarters to generate a forecast of four-quarter-ahead inflation, in this paper we proxy inflation expectations using an average of inflation over the prior four quarters. This change is driven in part by data constraints; for the Euro Area, the estimation sample could not start prior to 1983q1 if the former method were used. In Figure 11, we compare the two measures of inflation expectations and find that they are close for the US. 
Table 6: Comparison of HLW and LW (2003) Parameter Estimates

\begin{tabular}{|c|c|c|c|}
\hline Parameter & $\begin{array}{r}\text { HLW: } \\
\text { US }\end{array}$ & $\begin{array}{r}\text { LW (2003): } \\
\text { Current }\end{array}$ & $\begin{array}{l}\text { LW (2003) } \\
2003 \text { Vintage }\end{array}$ \\
\hline Sample & 1961q1-2016q3 & 1961q1-2016q3 & 1961q1-2002q2 \\
\hline$\lambda_{g}$ & 0.053 & 0.014 & 0.042 \\
\hline$\lambda_{z}$ & 0.030 & 0.042 & 0.058 \\
\hline$\sum a_{y}$ & 0.942 & 0.955 & 0.945 \\
\hline$\overline{a_{r}}$ & $\begin{array}{r}-0.071 \\
(4.063)\end{array}$ & $\begin{array}{r}-0.057 \\
(3.571)\end{array}$ & $\begin{array}{r}-0.098 \\
(3.81)\end{array}$ \\
\hline$b_{y}$ & $\begin{array}{c}0.079 \\
(3.136)\end{array}$ & $\begin{array}{c}0.041 \\
(2.078)\end{array}$ & $\begin{array}{r}0.043 \\
(1.63)\end{array}$ \\
\hline$c$ & 1.000 & 1.365 & 1.068 \\
\hline$\sigma_{\tilde{y}}$ & 0.354 & 0.351 & 0.387 \\
\hline$\sigma_{\pi}$ & 0.791 & 0.764 & 0.731 \\
\hline$\sigma_{y^{*}}$ & 0.575 & 0.603 & 0.605 \\
\hline$\sigma_{g}$ & 0.122 & 0.034 & 0.102 \\
\hline$\sigma_{z}$ & 0.150 & 0.260 & 0.323 \\
\hline$\sigma_{r^{*}}=\sqrt{c^{2} \sigma_{g}^{2}+\sigma_{z}^{2}}$ & 0.194 & 0.264 & 0.340 \\
\hline \multicolumn{4}{|l|}{ S.E. (sample ave.) } \\
\hline$r^{*}$ & 1.072 & 1.886 & 1.88 \\
\hline$g$ & 0.402 & 0.219 & 0.48 \\
\hline$y^{*}$ & 1.504 & 1.663 & 3.02 \\
\hline \multicolumn{4}{|l|}{ S.E. (final obs.) } \\
\hline$r^{*}$ & 1.528 & 3.151 & 2.61 \\
\hline$g$ & 0.548 & 0.288 & 0.63 \\
\hline$y^{*}$ & 1.988 & 2.925 & 4.23 \\
\hline
\end{tabular}

Notes: $t$ statistics are in parentheses; $\sigma_{g}$ is expressed at an annual rate. 
Figure 10: Comparison of HLW and LW (2003) Estimates
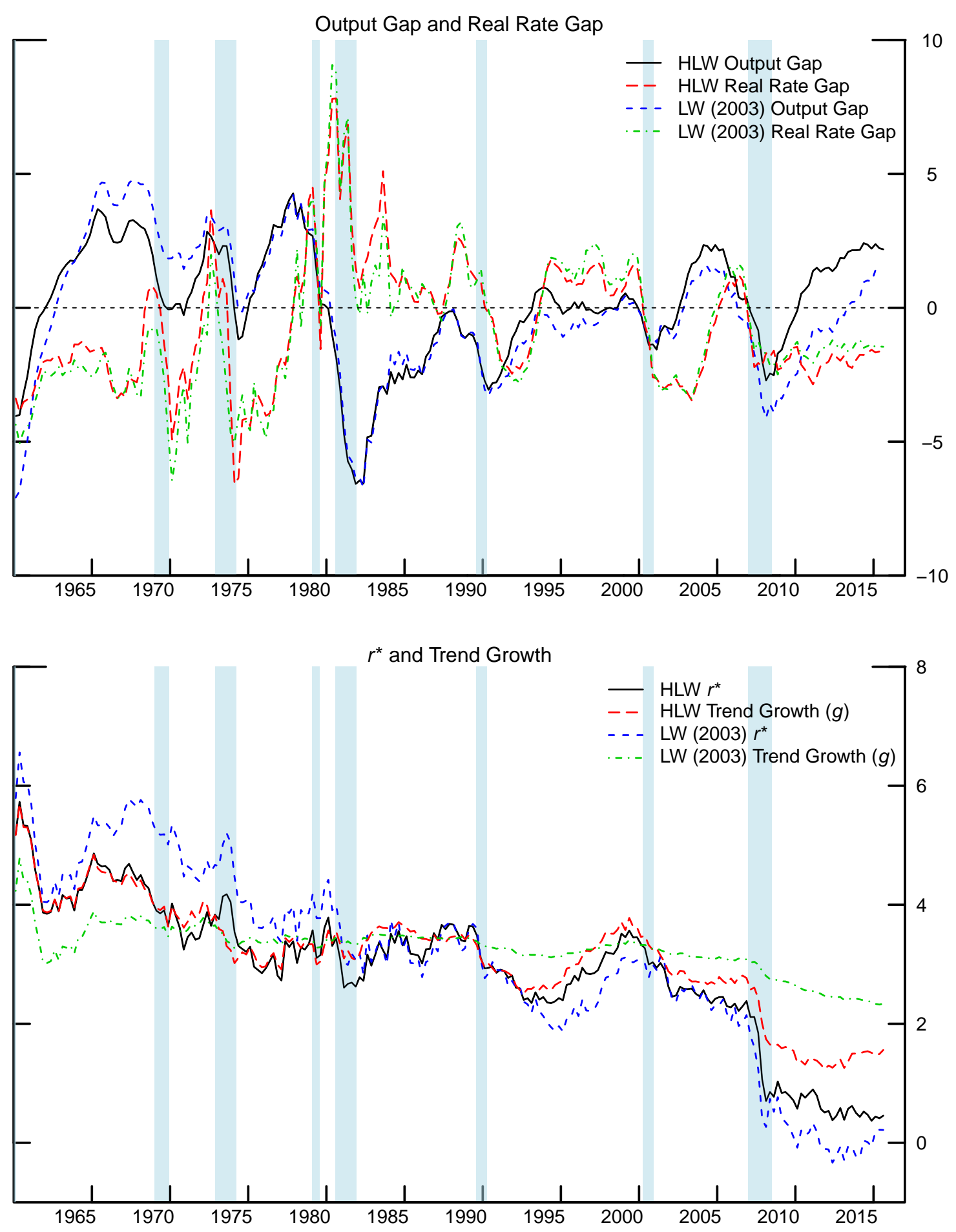
Figure 11: Comparison of HLW and LW (2003) Measures of Inflation Expectations

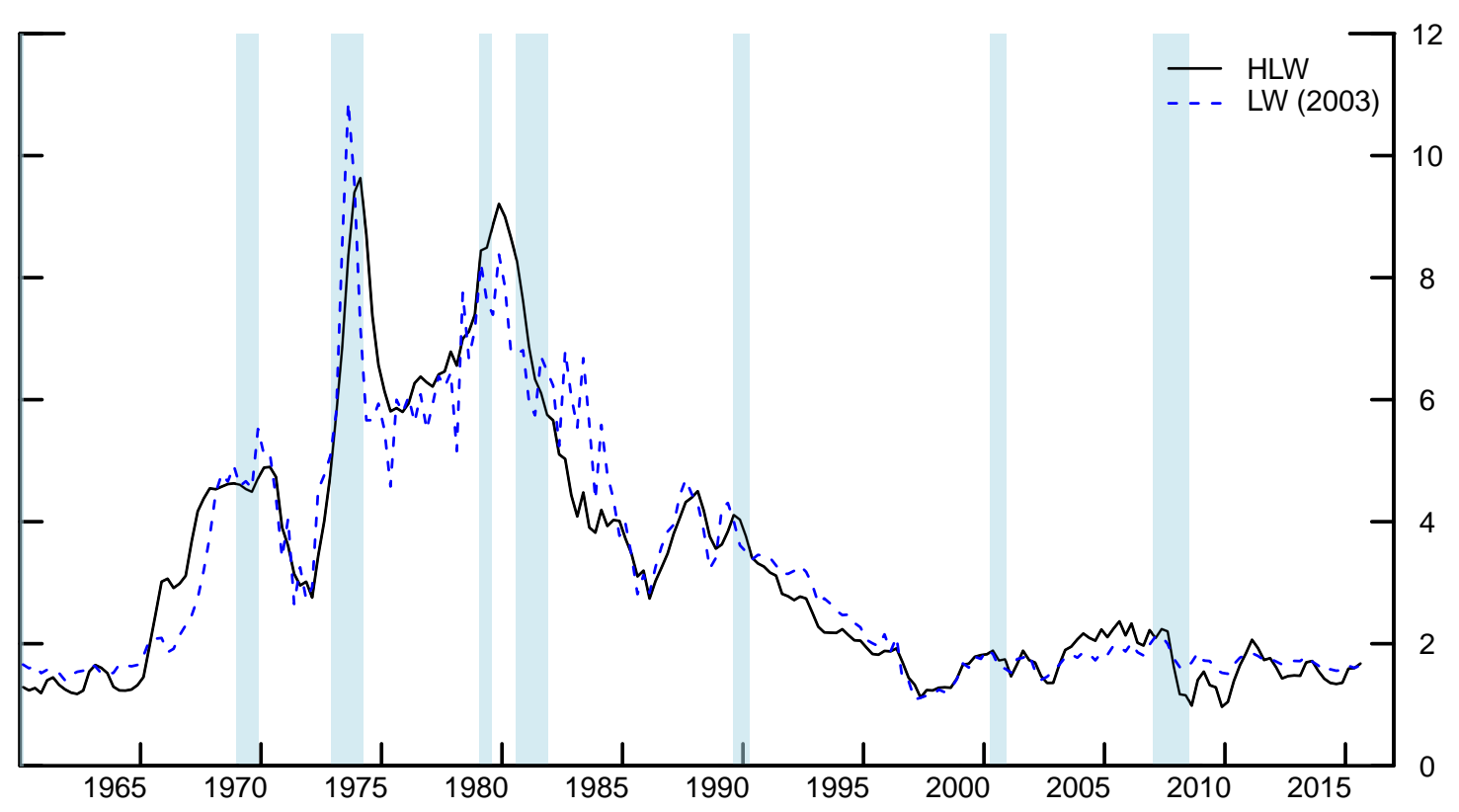

